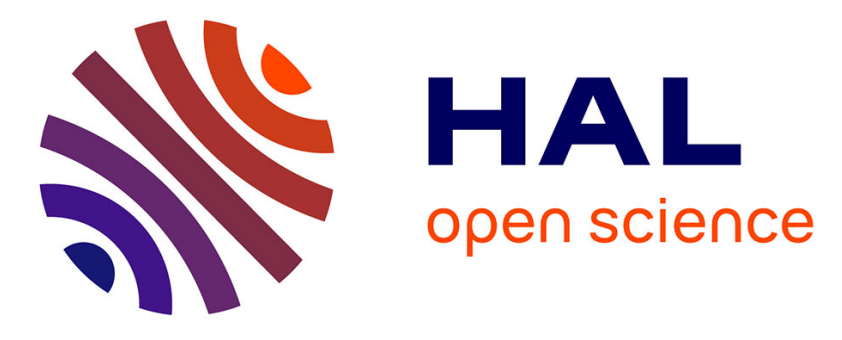

\title{
Miocene Ethiopian amber: a new source of fossil cryptogams
}

Valentine Bouju, Kathrin Feldberg, Ulla Kaasalainen, Alfons Schäfer-verwimp, Lars Hedenäs, William Buck, Bo Wang, Vincent Perrichot, Alexander Schmidt

\section{- To cite this version:}

Valentine Bouju, Kathrin Feldberg, Ulla Kaasalainen, Alfons Schäfer-verwimp, Lars Hedenäs, et al.. Miocene Ethiopian amber: a new source of fossil cryptogams. Journal of Systematics and Evolution, 2022, 60 (4), pp.932-954. 10.1111/jse.12796 . insu-03231697

\section{HAL Id: insu-03231697 https://hal-insu.archives-ouvertes.fr/insu-03231697}

Submitted on 21 May 2021

HAL is a multi-disciplinary open access archive for the deposit and dissemination of scientific research documents, whether they are published or not. The documents may come from teaching and research institutions in France or abroad, or from public or private research centers.
L'archive ouverte pluridisciplinaire HAL, est destinée au dépôt et à la diffusion de documents scientifiques de niveau recherche, publiés ou non, émanant des établissements d'enseignement et de recherche français ou étrangers, des laboratoires publics ou privés. 
Valentine Bouju ORCID iD: 0000-0003-3185-5047

Alexander Schmidt ORCID iD: 0000-0001-5426-4667

\title{
Miocene Ethiopian amber: a new source of fossil cryptogams
}

\section{Running title: Cryptogams from Miocene Ethiopian amber}

Valentine Bouju $^{1, *}$, Kathrin Feldberg ${ }^{2}$, Ulla Kaasalainen ${ }^{2}$, Alfons Schäfer-

Verwimp ${ }^{3}$, Lars Hedenäs ${ }^{4}$, William R. Buck ${ }^{5}$, Bo Wang ${ }^{6}$, Vincent

Perrichot $^{1}$, Alexander R. Schmidt ${ }^{2}$

${ }^{1}$ Univ Rennes, CNRS, Géosciences Rennes, UMR 6118, 263 avenue du Général

Leclerc, 35000 Rennes, France

${ }^{2}$ Department of Geobiology, University of Göttingen, Goldschmidtstraße 3, 37077

Göttingen, Germany

${ }^{3}$ Mittlere Letten 11, 88634 Herdwangen-Schönach, Germany

${ }^{4}$ Swedish Museum of Natural History, Department of Botany, Box 50007, SE-104 05

Stockholm, Sweden

${ }^{5}$ Institute of Systematic Botany, The New York Botanical Garden, Bronx, New York 10458-5126, U.S.A.

${ }^{6}$ State Key Laboratory of Palaeobiology and Stratigraphy, Nanjing Institute of Geology and Palaeontology and Center for Excellence in Life and Palaeoenvironment, Chinese Academy of Sciences, 39 East Beijing Road, 210008 Nanjing, China

* Authors for correspondence. Valentine Bouju. E-mail: valentine.bouju@univrennes1.fr

\begin{abstract}
Amber is renowned for the exceptional preservation state of its inclusions, allowing detailed morphological analysis and providing relevant environmental, This article has been accepted for publication and undergone full peer review but has not been through the copyediting, typesetting, pagination and proofreading process, which may lead to differences between this version and the Version of Record. Please cite this article as doi: $10.1111 /$ jse. 12796 .
\end{abstract}

This article is protected by copyright. All rights reserved. 
palaeoecological, geographical, and geological information. Amber deposits predominantly known from North America, Europe, and Asia, are considered to be rare on the continents that formed Gondwana. The recent discovery of fossiliferous amber deposits in Ethiopia therefore provides an inimitable opportunity to close gaps in the fossil record of African terrestrial biota, and to study organisms otherwise rare in the fossil record. Here we show that diverse cryptogams are preserved in highest fidelity in Miocene Ethiopian amber. We describe gametophyte fragments of four liverworts: Thysananthus aethiopicus sp. nov. (Porellales, Lejeuneaceae), Lejeunea abyssinicoides sp. nov. (Porellales, Lejeuneaceae), Frullania shewanensis sp. nov. (Porellales, Frullaniaceae), and Frullania palaeoafricana sp. nov. (Porellales, Frullaniaceae). Furthermore, we describe a pleurocarpous moss of the extant genus Isopterygium (Hypnales, Pylaisiadelphaceae) and a lichen representing the order Lecanorales. These new specimens represent the first amber fossils of liverworts, mosses, and lichens from the African continent and render Ethiopian amber one of the few worldwide amber deposits preserving bryophytes (mosses and liverworts) or lichens. Fossil species of Thysananthus were recorded in Eocene Baltic and Oligocene Bitterfeld as well as Miocene Dominican and probably also Miocene Mexican ambers. Fossils which can unequivocally be assigned to Lejeunea have only been found in Dominican amber, so far. Neotropical ambers contain only one taxon of Frullania to date, while the genus is most diverse in Baltic, Bitterfeld, and Rovno ambers, formed in temperate regions. The new fossils support a tropical to subtropical origin of Ethiopian amber. The new African liverwort fossils are included in an updated list of leafy liverworts described from worldwide Cenozoic ambers to date.

Graphical Abstract

This article is protected by copyright. All rights reserved. 


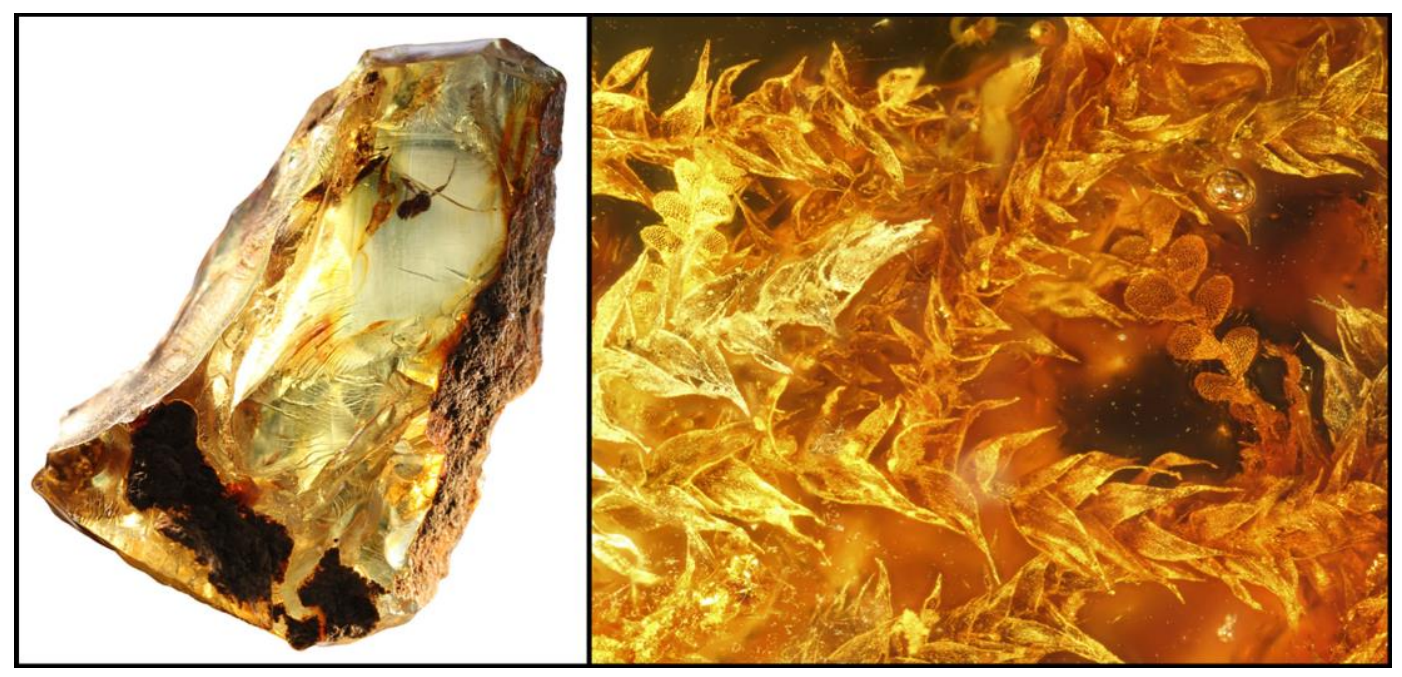

The first African amber fossils of liverworts, mosses, and lichens are reported from Miocene Ethiopian amber. The new fossils show an exceptional life-like preservation in crystal clear amber and four new species of liverworts are described. The cryptogam association, similar to that of Dominican amber, supports a tropical environment of Miocene Ethiopia.

Key words: Africa, amber, lichen, liverwort, Miocene, moss.

\section{Introduction}

Ancient tree resin provides fossils in an exceptional preservation state (Grimaldi, 1996; Taylor et al., 2009; Penney, 2010; Ragazzi \& Schmidt, 2011). These amber inclusions represent an important source of taxonomic, ecological or even environmental information which lead to a better understanding of the evolutionary and geographical history of some taxa, and a better knowledge of the palaeoenvironmental and geological context of a region (Penney, 2010; Wang et al., 2014; Schmidt et al., 2018; Zheng et al., 2018; Stilwell et al., 2020).

Most amber deposits are known from North America, Europe, and Asia, while the Gondwanan amber fossil record remains scarce (Schmidt et al., 2018). Recently, new amber deposits with fossil inclusions have been discovered in Ethiopia, representing the first fossiliferous amber deposit known from Africa. Schmidt et al. (2010) reported the first amber outcrop from Ethiopia with inclusions and observed diverse arthropods, fungi, bacteria, and palynomorphs. Discovery of further amber-bearing 
localities in Ethiopia multiplied the number of inclusions since then, among which fossils of plants were found (Bouju \& Perrichot, 2020).

Here we report diverse cryptogams from Ethiopian amber: eleven liverwort fossils representing four new species, numerous specimens of a pleurocarpous moss, and a lichen belonging to the Lecanorales. The association of the cryptogams, with sometimes several specimens and different species in a single amber piece, suggest that they were part of an epiphyte community in a tropical to subtropical forest area (Fig. 1).

The new fossils are exceptional because of their unequalled life-like preservation in crystal-clear amber and because they represent the first liverworts, mosses, and lichens from any African amber (Fig. 1). Fossil bryophytes from Africa have hitherto only been described from the rock record and represent thalloid liverworts and mosses, e.g., the potential complex thalloid liverwort Marchantites cyathodoides (Townrow) H.M.Anderson from the Triassic Molteno Formation of South Africa, and the moss Buthelezia mooiensis Lacey, Dijk \& Gordon-Gray from the Permian Estcourt Formation of South Africa (see Tomescu et al., 2018 for review). The number of cryptogam-bearing amber deposits is generally very low; so far, only eleven other worldwide amber deposits contain bryophytes (mosses and/or liverworts) (Ignatov \& Perkovsky, 2013; Katagiri, 2013; Heinrichs et al., 2018a; Katagiri \& Shinden, 2020), and only three other amber deposits are known to preserve fossil lichens (Kaasalainen et al., 2017a, 2017b, 2019).

An overview of all fossil leafy liverworts described from worldwide Cenozoic amber deposits to date is provided in order to update the comprehensive list published by

This article is protected by copyright. All rights reserved. 
Heinrichs et al. (2018a), because several new species have been described since then, and new combinations have been made (Table 1).

\section{Geological setting}

The cryptogams studied here are enclosed in eight amber pieces obtained from an Ethiopian amber trader on two occasions. The exact provenance of the pieces is unknown but is undoubtedly among the four localities that have been accessed by the trader (Fig. 2), down the gorges of rivers and affluent streams incising the northwestern Plateau of Ethiopia in North Shewa of the Amhara and of the Oromia regions. Ethiopian amber has initially been thought to be Late Cretaceous in age (Schmidt et al., 2010; Kiefert, 2015), but later this has been questioned (Coty et al., 2016; Perrichot et al., 2016) and analyses of further material including sporomorphs from the associated sediment, amber chemistry, and organismal inclusions indicate an early Miocene age (Perrichot et al., 2018; Bouju \& Perrichot, 2020). In all four localities, the amber is apparently excavated from the same siltstone, although in situ observations have been possible only in the locality of Woll, during a field trip by two of us (V.B. and V.P.) in June 2019 (Fig. 2D).

\section{Material and methods}

\subsection{Preparation, microscopy}

The amber is particularly translucent, with a green to red-yellowish coloration. In order to minimize light scattering during the investigation and to study both lower and upper side of the specimens, the surfaces of the amber pieces were ground and polished manually using a series of wet silicon carbide abrasive papers (grit from FEPA P $600-4000$, i.e., $25.8 \mu \mathrm{m}$ to $5 \mu \mathrm{m}$ particle size, Struers Inc.) to minimize light scattering during the investigation (Kettunen et al., 2019).

This article is protected by copyright. All rights reserved. 
A drop of water was applied to the upper surface of the amber and covered with a 0.06-0.08 mm thick glass coverslip (Menzel Inc., Braunschweig) to reduce light scattering from fine surface scratches and to improve optical resolution (Schmidt et al., 2012). The amber inclusions were examined under a Zeiss Stereo Discovery V8 dissection microscope and under a Zeiss AxioScope A1 compound microscope, equipped with Canon 5D digital cameras. In most instances, incident and transmitted light were used simultaneously. Oblique incident light was obtained using a gooseneck light guide of a Zeiss CL 1500 Eco cold light source. For an enhanced illustration of the three-dimensional inclusions, the light-microscopical images are digitally stacked photomicrographic composites from up to 99 individual focal planes using the software package Helicon Focus version 6.3.3 Pro (Kettunen et al., 2019).

\subsection{Repositories and institutional abbreviations}

Amber pieces studied herein are deposited in the collections of the Nanjing Institute of Geology and Palaeontology of the Chinese Academy of Sciences, Nanjing (NIGPAS) (pieces with collection numbers starting with PB), and the Geological Department and Museum of the University of Rennes 1, Rennes (IGR) (Table 2).

\section{Systematic palaeontology}

Phylum Marchantiophyta

Class Jungermanniopsida

Order Porellales

Family Lejeuneaceae

Subfamily Ptychanthoideae

Genus Thysananthus Lindenb. in Lehmann, 1844

This article is protected by copyright. All rights reserved. 
Fossil species Thysananthus aethiopicus V.Bouju, K.Feldberg, A.Schäf.-Verw. \& A.R.Schmidt, sp. nov.

Derivation of name: The specific epithet refers to Ethiopia, the country of origin of the amber in which the specimens are enclosed.

Holotype: PB23742 (housed in NIGPAS), single sterile liverwort gametophyte (Figs. $3 \mathrm{~A}-\mathrm{E})$.

Further specimens examined: PB23743 (housed in NIGPAS), upper parts of four sterile gametophytes (Figs. 3F, G); IGR.ET2020/010, upper part of one sterile gametophyte (Figs. 3H, I); IGR.ET2020/012, upper part of one sterile gametophyte (Fig. 1C).

Specific diagnosis: Incubously foliated liverwort with a ventral merophyte at least 4 cells wide. Lateral leaves complicate bilobed, consisting of an ovate lobe and an ovate lobule folded against the lobe forming a keel (Lejeunea-type lobule). The lobe apex is mostly rounded and plane to slightly involute. Cells are mostly elongate throughout the lamina. Lobule with 1-2 teeth on the free margin. Underleaves are roundedquadrate to ovate to obovate with a rounded-truncate to retuse apex.

Description: The description predominantly refers to the specimen PB23742 in which the highest number of characters is clearly visible (Figs. 3A-E; Supplementary Table 1). Upper portion of vegetative shoot, ca. $1.55 \mathrm{~mm}$ long, $0.35-0.6 \mathrm{~mm}$ wide with leaves, light yellowish brown to reddish brown (Figs. 3A, B). Stem ca. $90 \mu \mathrm{m}$ in diameter, cortical cells elongate, moderately thick walled; ventral merophyte $4-5$ cells wide; cells of the outer cortex oval in cross section, 5-10 $\mu \mathrm{m}$ long, 7.5-12.5 $\mu \mathrm{m}$ wide, cells of the medulla slightly larger, oval to rectangular, 7.5-17.5 $\mu \mathrm{m}$ long, $10-17.5 \mu \mathrm{m}$ wide (Fig. 3E). Lateral branch present, slightly smaller but quite similar to the main 
shoot (Fig. 1C). Leaves incubous, imbricate, plane to slightly concave, suberect and appressed to stem to subhorizontally spreading. Dorsal lobe ovate to oblong-ovate, margin entire, antical margin regularly arched, postical margin deeply curved along inner half, first evenly then abruptly curved toward apex along outer half, postical margin occasionally revolute, $270-430 \mu \mathrm{m}$ long, $180-200 \mu \mathrm{m}$ wide in the middle; apex mostly rounded, occasionally apiculate; median cells isodiametric to elongate, 10-15 $\mu \mathrm{m}$ long, 5-10 $\mu \mathrm{m}$ wide, up to 1.5 times as long as broad, regularly and moderately thickened, trigones not clearly visible, intermediate thickenings possibly lacking. Lobules ovate to rectangular, folded against the dorsal lobe forming a keel and an antical opening (Lejeunea-type, Fig. 3C), 140-190 $\mu \mathrm{m}$ long, 73-97 $\mu \mathrm{m}$ wide, ca. $0.3-0.5$ times the length of the lobe, convex, apical free margin truncate, terminating at the end of the keel, the keel forming a slight angle with the ventral leaf margin, lobule apex with a distinct multicellular tooth, 20-40 $\mu \mathrm{m}$ long, 15-35 $\mu \mathrm{m}$ wide at base, occasionally additional smaller tooth at the free margin. Underleaves imbricate, plane to concave, symmetrical, margins slightly decurrent, roundedquadrate to oval to obovate, widest part in the middle or the upper third (Figs. 3C, FI), $180-240 \mu \mathrm{m}$ long, $130-180 \mu \mathrm{m}$ at the widest part, $1-1.5$ times as long as wide; apex plane or recurved, rounded to truncate to retuse. Thin bundles of rhizoids originating at the bases of some underleaves. Sterile.

Remarks: Specimen PB23742 can easily be identified as a member of the Lejeuneaceae. It has incubously inserted, complicate bilobed leaves which are divided into a large dorsal lobe and a small ventral lobule, with the latter folded against the dorsal lobe forming a keel and enclosing the ventral leaf surface (Lejeunea-type). The undivided ("holostipous") underleaves and the ventral merophyte with more than four 
cells support an assignment to Lejeuneaceae subfamily Ptychanthoideae (Figs. 3C, FI).

Six gametophyte fragments from three other pieces of amber (PB23743, Figs. 3F, G; IGR.ET2020/010, Figs. 3H, I; IGR.ET2020/012, Fig. 1C) are morphologically in good accordance with the holotype PB23742 and are most likely conspecific. Specimens PB23743, IGR.ET2020/010, and IGR.ET2020/012 are very similar, especially the latter two are equal in size and all relevant characters are visible (Supplementary Table 1). However, there are also some differences. The additional specimens in PB23743 have narrower stems, the ventral lobules are up to $0.3-0.5$ times as long as the dorsal lobes, and while the form is similar, the apical tooth is not often visible and if it is, it is less coarse and mostly shorter (Fig. 3G). A second tooth on the free margins has not been seen in these specimens. The apical free margins of the lobules are not always clearly visible and occasionally seem to merge into the revolute postical lobe margin. Furthermore, the cells of the leaves are better preserved (Fig. 3G). The cells are isodiametric to mostly elongate, and the marginal cells are similar to the cells in the middle of the lobe. Underleaves are often deeply concave and a little broader than long (ca. 0.9 times as long as broad). One of the specimens in PB23743 is comparatively small, but its morphology corresponds well to the narrower parts of the other shoots, especially PB23742. The underleaves are similar to the smallest ones found in the other specimens; they are all long ovate to obovate with a rounded apex.

Subfamily Lejeuneoideae

Tribe Lejeuneeae

Genus Lejeunea Libert, 1820

This article is protected by copyright. All rights reserved. 
Fossil species Lejeunea abyssinicoides A.Schäf.-Verw., V.Bouju, K.Feldberg \&
A.R.Schmidt, sp. nov.

Derivation of name: The specific epithet refers to the extant African species Lejeunea abyssinica (Gola) Cufod. which now includes the very similar L. confusa E.W.Jones (Pócs et al., 2015).

Holotype: IGR.ET2020/009, sterile gametophyte fragment, associated with a moss and Frullania shewanensis (Fig. 4).

Specific diagnosis: Incubously foliated liverwort with a ventral merophyte at least 2 cells wide. Lateral leaves complicate bilobed, consisting of an obovate dorsal lobe and an oval ventral lobule which is folded against the lobe forming a keel (Lejeunea-type). The lobe apex is rounded and plane. Cells are isodiametric to slightly elongate. Underleaves are deeply bifid with lanceolate lobes.

Description: Portion of vegetative shoot, ca. $1.3 \mathrm{~mm}$ long, with leaves $96-160 \mu \mathrm{m}$ wide, light yellowish brown (Figs. 4A, B). Stem ca. $30 \mu \mathrm{m}$ in diameter, cortical cells elongate, moderately thick-walled; ventral merophyte $2(\sim 3)$ cells wide. Leaves incubous, distant to approximate, plane to slightly convex, erect spreading. Dorsal lobe obovate, margin entire, antical margin arched, free postical margin more or less straight, $180-320 \mu \mathrm{m}$ long, $150-200 \mu \mathrm{m}$ wide in the middle of the leaf; apex rounded; median cells of dorsal lobe isodiametric to slightly elongate, $12-25 \mu \mathrm{m}$ long, $15-17$ $\mu \mathrm{m}$ wide, up to twice as long as broad, regularly and moderately thickened, trigones medium sized. Ocelli not seen. Lobules oval to ovate, folded against the lobe forming a keel and an antical opening (Lejeunea-type; Fig. 4C), 0.3-0.4 times the length of the lobe, plane to inflated, free margin involute, ca. $120 \mu \mathrm{m}$ long, $112 \mu \mathrm{m}$ wide at the 
base. Underleaf deeply bifid (Fig. 4D), ca. $60 \mu \mathrm{m}$ long, $47 \mu \mathrm{m}$ wide at the broadest part, ca. up to 1.3 times as long as wide, lobes lanceolate. Sterile.

Remarks: The narrow ca. 2 cells wide ventral merophyte and the deeply bifid underleaves are in good accordance with subfamily Lejeuneoideae tribe Lejeuneeae (Gradstein, 2013). With $\sim 40$ extant genera, the Lejeuneeae are the largest tribe in Lejeuneaceae (Gradstein, 2013). The gametophyte fragment might be sterile but the small size, the ca. 2 cells wide ventral merophyte, the spreading, and entire dorsal lobes with a rounded leaf apex, the apparent lack of ocelli, and the small bifid underleaves allow an assignment to the large pantropical and warm-temperate genus Lejeunea.

Family Frullaniaceae

Genus Frullania Raddi, 1818

Fossil species Frullania shewanensis K.Feldberg, V.Bouju, Schäf.-Verw. \& A.R.Schmidt, sp. nov.

Derivation of name: The specific epithet refers to the North Shewa zone, were all reported Ethiopian amber deposits are located.

Holotype: IGR.ET2020/013b, sterile gametophyte fragment (Fig. 5).

Further specimens examined: IGR.ET2020/009, several gametophyte fragments, associated with the moss Isopterygium and the liverwort Lejeunea abyssinicoides (Fig. $6)$.

Specific diagnosis: Incubously foliated liverwort with a ventral merophyte $4-5$ cells wide. Lateral leaves complicate lobed, consisting of a suborbicular to oval to ovate dorsal lobe, and a saccate, helmet-shaped ventral lobule with a postical opening (Frullania-type) which is inserted remotely from the stem. A lanceolate to triangular 
stylus is often present. The dorsal lobe is subacute to acuminate. Cells are isodiametric to slightly elongate. Underleaves are oval and bifid with triangular, symmetric lobes.

Description: The description is predominantly based on the holotype specimen in IGR.ET2020/013b which shows the highest number of characters (Fig. 5, Supplementary Table 2). Gametophyte fragment, ca. $4.75 \mathrm{~mm}$ long, $0.42-0.74 \mathrm{~mm}$ wide with leaves, yellowish brown to brown (Figs. 5A, B). Short lateral branch (insertion not clearly visible) at the upper end, ca. $1.2 \mathrm{~mm}$ long, $0.18-0.48 \mathrm{~mm}$ wide with leaves; hemiphyll (basal branch leaf) not visible. Stem of main shoot dark brown, $42-48 \mu \mathrm{m}$ in diameter, cortical cells elongate, $15-51 \mu \mathrm{m}$ long, $6-9 \mu \mathrm{m}$ wide, moderately thick walled; stem of branch $20-25 \mu \mathrm{m}$ in diameter; ventral merophyte of main shoot 4-5 cells wide. Lateral leaves incubous, imbricate to contiguous, plane to slightly convex, subhorizontally spreading, bent to ventral side on branch. Dorsal lobe suborbicular to oval to broadly ovate, margin entire, apical part often slightly revolute, 318-444 $\mu \mathrm{m}$ long, 306-342 $\mu \mathrm{m}$ wide in the middle; apex subacute to mucronate to acuminate; marginal cells of dorsal lobes isodiametric, quadrate to hexagonal, 10-15 $\mu \mathrm{m}$ in diameter; median cells of dorsal lobes isodiametric to more elongate towards leaf base, quadrate to hexagonal to rectangular to oval at the leaf base, $12.5-25 \mu \mathrm{m}$ long, $10-15 \mu \mathrm{m}$ wide, up to twice as long as wide; cell walls regularly thickened, ca. $2.5 \mu \mathrm{m}$ thick, trigones small, triangular (Fig. 5F). Ocelli not seen. Ventral lobules small, saccate, helmet-shaped, inflated (Frullania-type; Figs. 5C-E); distant from stem $0.5-0.8$ times of their width, obliquely inserted (forming an angle of $20-30^{\circ}$ to stem), $120-150 \mu \mathrm{m}$ long, 54-108 $\mu \mathrm{m}$ wide, up to twice as long as wide, broadest part in the middle or upper third, opening slightly constricted and emarginate, cells isodiametric to elongate, quadrate to hexagonal to rectangular, 10-20 $\mu \mathrm{m}$ long, $7.5-15$ 
$\mu \mathrm{m}$ wide, up to 2.5 times as long as wide; stylus distinct, lanceolate, ca. $50 \mu \mathrm{m}$ long, base 1-2 cells wide, apex unicellular, 2-3 cells long (Fig. 5E). Branch leaves with narrower oval to ovate lobes with distinctly acuminate apices. Underleaves distant, plane to slightly convex in the lower half, margins not decurrent, oval, widest part in the middle, $132-222 \mu \mathrm{m}$ long, 96-156 $\mu \mathrm{m}$ wide, ca. 1-1.2 times as long as wide, bifid to ca. 1/3 of their length, lobes symmetrical, triangular, acute (Fig. 5C); cells of underleaves isodiametric to elongate, $10-18 \mu \mathrm{m}$ long, 9-16 $\mu \mathrm{m}$ wide, up to twice longer than wide, cells walls $2-5 \mu \mathrm{m}$ thick; underleaves of branches smaller and ca. twice as long as broad. Rhizoids not seen. Sterile.

Remarks: The fossil can be easily identified as a member of the extant genus Frullania which is characterized by complicate lobed leaves with a large dorsal lobe and a mostly saccate and inflated ventral lobule (Frullania-type, Figs. 5C-E). A stylus is often positioned between the lobule and the stem.

Specimen IGR.ET2020/009 (Fig. 6) is morphologically very similar to the holotype, with the sole difference, that the lobules are mostly explanate and that leaves with a plane lobule have broad triangular stylus 3-4 cells wide at base (Fig. 6D). The occurrence of explanate lobules is very common in many extant Frullania species, not only on fertile but also on vegetative shoots (e.g., Schuster, 1992; Vanderpoorten \& Goffinet, 2009). Examples from the African flora can be seen in Vanden Berghen's monography of African Frullania, e.g., F. longistipula Steph. (Vanden Berghen, 1976: fig. 18), F. purpurea Steph. (Vanden Berghen, 1976: fig. 19) or F. teneriffae (F.Weber) Nees (Vanden Berghen, 1976: fig. 28). More examples can be seen in figs. $30,35,43,44$, and 49 of the same publication. 
Fossil species Frullania palaeoafricana, K.Feldberg, V.Bouju, A.Schäf.-Verw. \& A.R.Schmidt, sp. nov.

Derivation of name: The specific epithet refers to the origin of the amber in prehistoric Africa.

Holotype: IGR.ET2020/015, single liverwort gametophyte fragment (Fig. 7). Specific diagnosis: Incubously foliated liverwort with a ventral merophyte $\sim 6$ cells wide. Lateral leaves complicate lobed, consisting of an ovate dorsal lobe, and a saccate, cylindrical ventral lobule with a postical opening (Frullania-type). Lobe apex rounded. Lobule inserted very close to the stem, with a short beak on the outer margin. Underleaves suborbicular to broadly oval, bifid, lobes short triangular, asymmetric, with rounded or subacute apices.

Description: Upper portion of gametophyte, ca. $1.34 \mathrm{~mm}$ long, $0.55-0.97 \mathrm{~mm}$ wide with leaves, light brownish grey, unbranched (Figs. 7A, B). Stem of main shoot greyish, ca. $50 \mu \mathrm{m}$ in diameter, cortical cells elongate, 15-25 $\mu \mathrm{m}$ long, 10-12 $\mu \mathrm{m}$ wide, moderately thick walled (Fig. 7E); ventral merophyte 6-7 cells wide. Lateral leaves incubous, closely imbricate, plane to slightly concave, subhorizontally spreading. Dorsal lobe ovate, margin entire, apical part often slightly involute, 318$444 \mu \mathrm{m}$ long, 306-342 $\mu \mathrm{m}$ wide in the middle; apex rounded; upper marginal cells of leaves isodiametric to slightly elongate, $10-17 \mu \mathrm{m}$ long, $8-12 \mu \mathrm{m}$ wide, up to 2.5 times as long as broad; median cells of dorsal lobes isodiametric to elongate, 12-25 $\mu \mathrm{m}$ long, 13-24 $\mu \mathrm{m}$ wide, up to twice as long as broad, cell walls $2.5 \mu \mathrm{m}$ thick (Fig. 7D). A row of enlarged cells near the base of one leaf indicates the presence of ocelli but could also represent damaged cells (Fig. 7D). Ventral lobules large, helmet-shaped with a short beak, not inflated, ca. 1/4 the size of the lobe (Figs. 7B, C), inserted very 
close to stem, $228-240 \mu \mathrm{m}$ long, ca. $138 \mu \mathrm{m}$ wide in the middle [many obscured], broadest part in the middle, opening very slightly constricted, weakly or not emarginate; lobule cells isodiametric to slightly elongate; insertion of lobule slightly oblique, with opening oriented toward stem; stylus not seen. Underleaves imbricate, concave in the lower half, margins decurrent, orbicular to suborbicular, widest part in the middle (Fig. 7C), 222-230 $\mu \mathrm{m}$ long, $270-330 \mu \mathrm{m}$ wide in the middle, ca. $0.7-0.8$ times as long as wide, bifid up to $1 / 4$ of the leaf length, lobes asymmetric, broadly triangular, tips rounded to subacute; cells isodiametric to slightly elongate, $12-18 \mu \mathrm{m}$ long, 9-16 $\mu \mathrm{m}$ wide, up to twice as long as wide, walls ca. $3 \mu \mathrm{m}$ thick. Rhizoids not seen. Sterile.

Remarks: The complicate-bilobed leaves with saccate ventral lobules with postical openings (Frullania-type; Figs. 7B, C) as well as the presence of bifid underleaves (Fig. 7C) clearly identify the new fossil as a member of the extant genus Frullania. Phylum Bryophyta

Class Bryopsida

Order Hypnales

Family Pylaisiadelphaceae

Genus Isopterygium Mitten, 1869

Specimens examined: IGR.ET2020/009 (Figs. 1A, B); IGR.ET2020/011 (Fig. 8)

Description: Plants pleurocarpous, shoots $1.2-7.5 \mathrm{~mm}$ long, irregularly and relatively sparsely branched, branching angle $45-90^{\circ}$ (Fig. 8A). Foliation complanate or subcomplanate, in some stem portions leaves slightly homomallous, lateral, dorsal and ventral leaves similar in size, 200-290 $\mu \mathrm{m}$ long and 60-120 $\mu \mathrm{m}$ wide, dorsal and ventral leaves symmetric, lateral leaves often slightly asymmetric (Figs. 8B, C). Leaf 
margin narrowly recurved in lower leaf, often to mid-leaf and sometimes further up, above denticulate. Laminal cells smooth, long and narrow, ca. 35-75 x 5-6 $\mu \mathrm{m}$, alar cells quadrate or rectangular in a few rows along basal leaf margin (Figs. 8B, C).

Remarks: Although Isopterygium is characterized by filamentous pseudoparaphyllia, we were unable to observe them in the present specimen. They are often hidden among the leaves and the latter cannot be removed in amber fossils. However, the predominantly complanate or subcomplanate habit, recurved leaf margins that are denticulate above, long and narrow laminal cells, and the relatively few and somewhat widened alar cells show that this a member of Isopterygium.

Phylum Ascomycota

Class Lecanoromycetes

Order Lecanorales

Specimens examined: PB23742, lichen fragment (Fig. 9).

Description: Thallus fragment $0.82 \mathrm{~mm}$ long, $0.65 \mathrm{~mm}$ wide and $0.10-0.17 \mathrm{~mm}$ thick, foliose (Fig. 9A). Stratification of the thallus showing an upper cortex with a photobiont layer, an internal medulla layer, and a looser lower layer but no lower cortex visible (Fig. 9B). Upper cortex 18-37 $\mu \mathrm{m}$ thick, dark-brown (Fig. 9C), with compact cortical hyphal network, and a layer of 3-4 $\mu \mathrm{m}$ diameter cells directly beneath the cortex. Medulla layer reddish-brown and composed of a dense fungal hyphal network, less agglutinated than the cortex hyphae. Lower layer of the thallus composed of $0.77-3.08 \mu \mathrm{m}$ wide loose and messy hyphae with similar reddish brown color as the medullar hyphae (Fig. 9D).

Remarks: The absence of lower cortex and the presence of a loose hyphal network on the lower side is reminiscent to hypothallus structures present in some extant lichen 
taxa, such as species of Pannaria (Pannariaceae) and Phyllopsora (Ramalinaceae)

(Passo et al., 2004; Elvebakk \& Elix, 2006; Kistenich et al., 2019). The single lichen fragment does not, however, provide enough information to be identified more precisely.

\section{Discussion}

\subsection{Preservation and diversity}

In contrast to the Ethiopian amber described by Schmidt et al. (2010), which was devoid of cryptogam inclusions, the samples obtained more recently contain diverse bryophytes and a lichen. The 14 fossils reported here were found in a relatively small number of eight amber pieces of a maximum size of $3 \mathrm{~cm}$. The translucence of the Ethiopian amber renders it an interesting material to study as the morphological details of plants, arthropods, and fungi can easily be observed in the crystal-clear matrix. Furthermore, the preservation of its inclusions is life-like, three-dimensional, and with cellular fidelity, see for instance the teeth on the lobules of Thysananthus (Fig. 3C). This fidelity equals, if not exceeds, that known from other Miocene Hymenaea ambers such as Dominican and Mexican amber.

The majority of liverwort fossils described from ambers belong to the predominantly leafy Jungermanniidae, while thalloid forms are exceptionally rare. Within Jungermanniidae there seems to be some preservation bias. The mainly epiphytic Porellales, and especially Lejeuneaceae and Frullaniaceae, are very diverse, while Jungermanniales are represented by significantly less species (Feldberg et al., 2014, 2018, 2021a, 2021b; Heinrichs et al., 2018a, 2018b; Katagiri, 2018; Mamontov et al., 2018, 2019; Li et al., 2020). The Porellales show several distinct characters, for example the incubously inserted, complicate lobed lateral leaves with a large dorsal

This article is protected by copyright. All rights reserved. 
lobe and a smaller ventral lobule, which is generally folded onto the ventral side of the dorsal lobe. A ventral row of underleaves or amphigastria is often present, the oftenassociated rhizoids are bundled, and branches are lateral.

\subsection{Classification of fossil liverworts}

Fossil material does not always display all relevant characters; therefore, a classification can be challenging. While generic assignments are often possible with high confidence, a comparison with extant species and assignments to extant subgenera or sections are much more difficult (Bechteler et al., 2017a; Heinrichs et al., 2018a). Furthermore, many characters in extant lineages are homoplastic and occur in different groups which are not necessarily closely related, and cryptic speciation is very common (Heinrichs et al., 2010, 2018a; Dong et al., 2012; Yu et al., 2013; Sukkharak \& Gradstein, 2014, 2017; Renner, 2015, 2017, 2020; Wang et al., 2016; Bechteler et al., 2017a, 2017b; Carter et al., 2017). Furthermore, a comparison of the new fossil species with previously described material from other amber deposits is very important. Long-distance dispersal can play an important role in shaping the distribution of extant liverworts and therefore, extant species often inhabit extensive intercontinental areas (Vanderpoorten et al., 2010; Carter et al., 2017). A possible occurrence of one fossil Frullania in two widely separated amber deposits, as has already been documented (Konstantinova et al., 2012).

\subsection{Lejeuneaceae}

Extant Lejeuneaceae are very abundant in the tropics and represent the largest family of leafy liverworts with ca. 1000 species (Gradstein, 2013; Söderström et al., 2016; Sukkharak \& Gradstein, 2017). They make up a large part of the epiphytic liverwort diversity in humid tropical forests and contain many epiphylls (Pócs, 1996; Wilson et 
al., 2007). Lejeuneaceae are characterized by incubously inserted, complicate bilobed leaves which are divided into a large dorsal lobe and a small ventral lobule, with the latter folded against the dorsal lobe forming a keel and enclosing the ventral leaf surface (Lejeunea-type), as well as underleaves which can be entire ("holostipous") or bifid, or occasionally also lacking. Despite the progress to unravel the often very complicated taxonomy, the classification of Lejeuneaceae genera and species is often difficult and depends on characters like the presence of ocelli, dentation of the lobule, and stem characters (Gradstein, 2013). Especially important are characters of the female involucrum and the perianth.

Until now, 30 fossil Lejeuneaceae species from 17 genera have been described from six amber deposits (Heinrichs et al., 2018a, 2018b) (Table 1). In accordance with the extant center of distribution in tropical regions, the majority has been found in tropical Dominican and Mexican ambers. One species has been found in Eocene Indian amber (Heinrichs et al., 2016a), three species have been described from Palaeogene Baltic and Bitterfeld ambers (Grolle, 1984a, 1985a) which were not produced under tropical climates (Kaasalainen et al., 2017b; Sadowski et al., 2017; Rikkinen \& Schmidt, 2018), and one from Ukrainian Rovno amber (Mamontov et al., 2013) (Table 1). The discovery of two species of the genera Thysananthus and Lejeunea in Ethiopian amber increases the number of amber deposits containing Lejeuneaceae to seven (refer to Table 1).

Thysananthus aethiopicus belongs to the subfamily Ptychanthoideae, which is characterized by wide ventral merophytes and undivided ("holostipous") underleaves. Several important diagnostic characters are lacking in the fossils, e.g., fertile structures, or are not well preserved, e.g., the lobe cells. While the median cells of the 
leaf lobes are clearly elongated, the trigones are not clearly visible, and the presence of intermediate thickenings remains questionable. However, the presence of elongated leaf lobe cells in combination with the apparent lack of a stem hyalodermis (Fig. 3E), the wide ventral merophyte, and the suberect-convolute, appressed leaves on some shoots (Figs. 3A, B) clearly separate the fossil from most other genera of Ptychanthoideae.

The most similar genera are Thysananthus and Spruceanthus. Both genera have a pantropical distribution with a center of diversity in Asia and few species in Africa and the Neotropics. Both genera are characterized by robust stems with wide ventral merophytes, the lack of a stem hyalodermis consisting of strongly enlarged epidermal cells, leaves which are subhorizontally spreading when moist, leaf lobes with sometimes upcurved ventral margins, and often inflated, toothed lobules with oblique or truncate apices (Sukkharak \& Gradstein, 2017; Wang et al., 2016). Vegetative material can be best distinguished by the form of the lobe cells. The median lobe cells of Thysananthus are elongate hexagonal with thin walls and large cordate trigones, while the median lobe cells of Spruceanthus are rarely elongated and generally isodiametric with small to medium, simple triangular or triradiate trigones. Elongated cells in Spruceanthus are often restricted to basal lobe portions and if the cells are elongated in the middle part, the length: width ratio is not as high as in Thysananthus and the cells often have broad, truncate ends. Furthermore, Spruceanthus has 1-3 lobule teeth which are generally small, while Thysananthus has $0-4$ lobule teeth which can be small and few-celled, long and linear, or large and triangular. Large teeth can consist of up to 12 cells (Sukkharak, 2015; Sukkharak \& Gradstein, 2014). Because of the large lobule teeth (Figs. 3B, C), the length: width ratio of the mostly 
elongated lobe cells which are ca. 1.5 times as long as wide, and the appressed lateral leaves of some fossils, we assign the fossil to Thysananthus.

The genus Thysananthus Lindenb. (now including Mastigolejeunea; Sukkharak \& Gradstein, 2017) is represented by three fossil species and one specimen only identified at genus level (Table 1). With 30 extant species, Thysananthus is the largest extant genus of Lejeuneaceae subfamily Ptychanthoideae. Thysananthus aethiopicus sp. nov. is the fourth fossil species assigned to this genus (Heinrichs et al., 2018a; Feldberg et al., 2021a) (Table 1). The fossil shows similarities to other Thysananthus fossils from Miocene Dominican and Eocene Baltic amber in the general habit but can easily be distinguished (Gradstein, 1993; Grolle \& Meister 2004 as Mastigolejeunea; Sukkharak \& Gradstein, 2017; Yu et al., 2020). The extinct T. bidentulus (Gradst.) Sukkharak \& Gradst. and T. weiweianus Yu et al. as well as the extant T. auriculatus (Wilson \& Hook) Sukkharak \& Gradst. have been described from approximately 1520 million-year-old Miocene Dominican amber (Gradstein, 1993; as Mastigolejeunea). Thysananthus bidentulus is larger than T. aethiopicus, has more broadly rounded lobe apices, more narrow and elongate lobules which are gradually merging into the free ventral margin of the lobe, and underleaves which are more obdeltoid. The leaf cells become smaller towards the margin, and the two lobule teeth are only one-celled (Supplementary Table 3). Thysananthus auriculatus is an extant species distributed in Africa as well as America and is superficially similar but has one-toothed lobules (Wigginton, 2004; Sukkharak \& Gradstein, 2014). This species is also significantly larger than the new fossil and the apical free margin of the lobules is oblique, continuing into the ventral margin of the leaf lobe (Supplementary Table 3). Thysananthus contortus (Göpp. \& Berendt) Sukkharak \& Gradst. from Baltic and 
Bitterfeld amber is also much more robust, and the lobules are much larger in relation to the lobes, obovate to spatulate, and bear up to 4 teeth on the free margin. Thysananthus weiweianus is also significantly larger and can be differentiate by the presence of 0-1 small blunt tooth. Furthermore, a fossil of Thysananthus sp. has been described from ca. 15-23 million-year-old Mexican amber (Scheben et al., 2014; Heinrichs et al., 2015a; as Mastigolejeunea). The fossil described by Scheben et al. (2014) has only been assigned at genus level due to the unclear structure of the lobule and the lack of reproductive structures, and as many characters are not visible it is difficult to compare. The specimen is larger, the apices of the lateral leaves are more broadly rounded, and the form of the underleaves differs. Underleaves in $T$.

aethiopicus are often retuse, but in $T$. $\mathrm{sp}$. the retuse portion is also distinctly revolute. The cells of the lateral leaves are mostly collapsed and only rarely clearly elongate, while the cells of the underleaves are mostly intact and elongate (Supplementary Table 3).

Relatively young ambers can also contain extant species, for example Thysananthus auriculatus in Dominican amber (Gradstein, 1993). A thorough comparison with the extant diversity is therefore important. However, a comparison of T. aethiopicus with the extant species is difficult because it is not discernible if the lobes of T. aethiopicus are auriculate. Furthermore, the insertion of the lobules is not visible, and the material is sterile. Superficially, T. aethiopicus resembles T. turgidus (Steph.) Sukkharak \& Gradst. from West Africa. When dry, this species has suberect and convolute leaves, which resemble specimen PB23743 (Fig. 3F). But it differs from the fossil in having no or only one blunt tooth on the outer free margin of the lobule which also differs in shape (Sukkharak \& Gradstein, 2014). The large and conspicuous lobule teeth also 
distinguish T. aethiopicus from other extant African species, e.g., T. humilis

(Gottsche) Sukkharak \& Gradst., T. nigrus (Steph.) Sukkharak \& Gradst., and T. spathulistipus (Reinw., Blume \& Nees) Lindenb., which all have more or less inconspicuous lobule teeth.

Extant Thysananthus is subdivided into the subgenera Thysananthus and Mastigolejeunea (Spruce) Sukkharak \& Gradst. which show a considerable morphological overlap and are difficult to distinguish, especially when only sterile material is at hand (Sukkharak \& Gradstein, 2017). Therefore, an assignment of the fossil material to one of the subgenera is not possible.

Until now, the genus Lejeunea was represented by four species from Miocene Dominican amber (Lee et al., 2017) and L. abyssinicoides sp. nov. is the first fossil described from outside of the Neotropics (Table 1). The most conspicuous difference between the new species and those previously described from Dominican amber is the larger size of the latter. However, it is possible that the small size of $L$. abyssinicoides is due to its fragmentary nature, and it might represent a detached branch. Apart from the size, the new species can be differentiated by some additional characters. Lejeunea miocenica Heinrichs et al. has apiculate dorsal leaf lobes and larger underleaves with broader lobes. Lejeunea hamatiloba G.E.Lee et al. has falcate dorsal lobes with triangular apices. Lejeunea resinata G.E.Lee et al. has dorsal lobes with an arched antical and a nearly straight postical margin similar to L. abyssinicoides but differs in having larger underleaves with additional lateral teeth, more thin-walled cells, and toothed lobules which are smaller in relation to the lobes and have a curved antical margin. Lejeunea urbanioides G.E.Lee et al., is the most similar species, but also 
differs in the shape of the underleaves which have broader lobes and also the lobules which have distinct apical teeth and a curved antical margin.

Many extant species have similarly small and bifid underleaves with narrow lobes, e.g., the pantropical L. adpressa Nees (incl. L. anisophylla Mont.), the pantropical $L$. papilionacea Prantl, the Asian L cocoes Mitt., and L. abyssinica from Africa. The most similar species is $L$. abyssinica which is small and has very similar underleaves and lobules. The species is widely distributed in tropical Africa, where it grows epiphytically on roots and trunks as well as occasionally epiphyllously. But while the postical margin of the lateral leaves is rather straight in the fossil species, the postical margin of L. abyssinica is strongly arched (Jones, 1972; Wigginton, 2004; as the synonymous species $L$. confusa). Therefore, the fossil material most probably represents a new and now extinct species.

\subsection{Frullaniaceae}

The Frullaniaceae are another lineage of mainly epiphytic leafy liverworts within the Porellales and one of the most species-rich taxa of leafy liverworts. Frullania is the only extant genus and morphologically well circumscribed. However, it has a very complex subgeneric taxonomy (e.g., Hentschel et al., 2009a, 2015; Bombosch et al., 2010; Heinrichs et al., 2010; Ramaiya et al., 2010; von Konrat et al., 2012, 2013; Carter et al., 2017) and includes several very difficult species complexes, which show wide distribution areas, but contain semicryptic to cryptic species which are often endemic to smaller areas of this range (e.g., Bombosch et al., 2010; Heinrichs et al., 2010). Due to the difficult species delimitations, ca. 2000 species names have been published since its inscription (von Konrat et al., 2010) of which 576 are currently accepted (Söderström et al., 2016; Mamontov et al., 2017). The genus has its center of 
diversity in humid tropical regions but is also distributed in temperate as well as arctic and alpine areas. The plants are usually characterized by a creeping habitus with lateral branches and leaves which are divided into a dorsal lobe, a ventral laminar stylus, and a ventral lobule which is often saccate with a postical opening and encloses the dorsal leaf surface (Frullania-type). Bundles of rhizoids originate at the base or in the middle of the often bilobed underleaves. Androecia are formed on short branches and the gynoecia terminal on the main axis or on short branches as well. The perianth is beaked and typically provided with sharp keels or ridges often with surface ornamentation (Schuster, 1992; Hentschel et al., 2009a).

Frullaniaceae are the most diverse group of liverworts found as amber inclusions (Feldberg et al., 2018, 2021a, 2021b; Heinrichs et al., 2018a; Mamontov et al., 2019; Li et al., 2020). The extant genus Frullania Raddi is represented by 16 fossil species dating from the mid-Cretaceous to the Miocene. Extinct representatives of the family are Protofrullania cornigera Heinrichs et al., from Cretaceous Burmese amber, and probably Kaolakia from Cretaceous Alaskan amber as well as Pseudofrullania hamatosetacea (Grolle) Heinrichs et al., from Cenozoic Bitterfeld amber.

Frullania is most diverse in Cenozoic ambers of Europe, with eight currently accepted species from Baltic and Bitterfeld amber (Grolle, 1985b; Grolle \& Meister, 2004; Heinrichs et al., 2018a; Feldberg et al., 2018), five species from Rovno amber (Mamontov et al., 2015a, 2017, 2018, 2019, 2020; Feldberg et al., 2021a), and one species occurring in all three deposits (Konstantinova et al., 2012) (Table 1). Additionally, one representative of Frullania from Miocene Dominican amber was described at the subgeneric level (Heinrichs \& Schmidt, 2010) and is probably also present in Rovno amber (Konstantinova et al., 2012) (Table 1). The oldest known 
representatives of the extant genus Frullania are three species from Cretaceous Burmese amber (Hentschel et al., 2009b; Heinrichs et al., 2012, 2018a; Feldberg et al., 2021a, 2021b; Li et al., 2020).

The taxa described here are two of the few representatives from tropical amber and clearly represent two new species. Frullania palaeoafricana sp. nov. (Fig. 7) differs from Frullania shewanensis sp. nov. (Figs. 5, 6) in several important characters. The lobes of the lateral leaves are broadly rounded and not subacute to acuminate (Figs. 5D, 6B, 7A, B, D), the lobules are bigger in relation to the lobes and are inserted close to the stem (Figs. 5C, E, 7C), and the underleaves are more or less orbicular, decurrent, and bifid into very broad, asymmetrical segments (Fig. 7C) instead of of ovate, not decurrent, and bifid into symmetrical, triangular segments (Figs. 5C, 6D). Furthermore, ocelli were not seen in F. shewanensis sp. nov. while they are possibly present in F. palaeoafricana sp. nov. (Fig. 7D).

Because the new fossils are sterile it is not possible to assign them to extant subgenera or sections with confidence. Furthermore, the subgeneric classification of Frullania is still a matter of much controversy (e.g., Hentschel et al., 2009a, 2015; Uribe, 2011). With its remote lobules and bifurcated underleaves $F$. shewanensis resembles members of the extant subgen. Diastaloba, which occurs in tropical America, Africa, Asia, and Oceania. However, this subgenus was resolved as paraphyletic in molecular phylogenetic studies and the characteristic remote "Diastaloba"-lobules are found in several independent lineages (Hentschel et al., 2009a, 2015). Other fossil species with remotely inserted, small lobules are F. baltica Grolle from Baltic and Bitterfeld amber, as well as a specimen of the subgenus cf. Diastaloba from Dominican amber. Frullania baltica is very similar in size and the 
form of lobes, lobules, and underleaves, but the lobes are broadly rounded and the underleaves have lateral teeth. The specimen from Dominican amber is much larger, has narrower, less arched dorsal lobes with a rounded apex, and underleaves with lateral angulations or teeth. The only similar sized species with apiculate lobes is $F$. acutata Caspary from Baltic amber, but it clearly differs from $F$. shewanensis in having lobules which are larger in relation to the dorsal lobes, more closely inserted to the stem, and with four mammillose cells at the basal half. Furthermore, the underleaves of $F$. shewanensis are oval to ovate with entire margins, while underleaves on the main stem of $F$. acutata are rectangular with more or less straight margins, and coarse apical teeth at the base of the lobes.

Frullania palaeoafricana is also difficult to assign. It is similar to subgen. Frullania (fide Lima et al., 2020) in having large lobules inserted close to the stem, lobes with elongate cells in the middle, and probably ocelli. It differs from this subgenus in having broadly rounded lobes instead of apiculate ones, and underleaves without any lateral teeth. However, the fossil represents only a rather small shoot fragment and both characters can be rather variable on one plant. The flat, slightly asymmetric lobules with a short beak resemble those found in subgenera Chonanthelia and Trachycolea but since the insertion is always obscured the form of the complete lobule is not clearly discernible.

Species from Baltic and Bitterfeld amber with large lobules inserted close to the stem are F. truncata Caspary, F. schumannii (Caspary) Grolle, and F. grabenhorstii. But the lobes of these species are inflated, symmetrical, and not beaked. 
Frullania shewanensis closely resembles the extant $F$. apiculata (Reinw. et al.) Nees (Diastaloba I; Hentschel et al., 2009a, 2015), a pantropical species with oval, rounded mucronate lobes, small lobules inserted remotely from the stem, and ovate bifurcated underleaves without lateral teeth (compare Wigginton, 2004: fig. 139). The fossil mainly differs in having less narrow lobules which are ca. twice as wide as long, instead of 2-2.6 times as wide as long. Frullania apiculata is widely distributed in Asia and Oceania and has a more restricted range in Africa (West and East Africa and East African Islands; Vanden Berghen, 1976; Wigginton, 2004). Another somewhat similar pantropical extant species with apiculate lobes and remotely inserted lobules is $F$. serrata Gottsche, but its gametophytes are generally more than twice as wide as the fossil and the underleaves often have an undulatecrisped margin (Wigginton, 2004).

Frullania palaeoafricana also resembles some of the extant Frullania species described from Africa (Vanden Berghen, 1976; Wigginton, 2004). African species with large, beaked lobules closely inserted to the stem and similarly shaped underleaves are F. depressa Mitt. and F. trinervis (Lehm.) Drége of subgenus Chonanthelia as well as F. caffraria Steph. and F. spongiosa Steph. of subgenus Trachycolea (compare Wigginton, 2004: figs. 147, 149, 150, 155).

\subsection{Pylaisiadelphaceae}

The genus Isopterygium includes 145-170 species (Frey \& Stech, 2009; Iwatsuki \& Ramsay, 2012), with more than 60 reported from Africa (O'Shea, 2006). Because the African members of the genus were not revised except for small geographical regions (Hedenäs \& Watling, 2005), we lack comprehensive data on the African members of the genus. For this reason, we refrain from trying to place our material within an 
extant taxon. Most of the African species have few and small alar cells but some, like the predominantly West African Isopterygium conangium Broth. (type material illustrated in Potier de la Varde, 1933-1936) and the Malagasy I. combae Besch. (=I. appressum Renauld and Cardot; illustration in Renauld \& Cardot, 1915), have groups of more numerous and slightly widened alar cells that approach those of our specimen in appearance.

There are few earlier reports of fossil Isopterygium. Isopterygium minutirameum was reported from Rovno amber (Ukraine, late Eocene) by Ignatov \& Perkovsky (2011), and a plant looking very much like an Isopterygium, but with prorate cell ends, Isopterygiites proratus J.-P. Frahm and Preussing, was found in limnic-fluviatile mid-Miocene sediments in Sachsen, Germany (Frahm et al., 2007). Isopterygium species grow mainly in humid terrestrial habitats, on substrates like tree stems and bases, decaying wood, soil, litter, or rocks, although some species occur in other habitats, such as wetlands (Ireland, 1992; Hedenäs \& Watling, 2005). The genus is most speciose in tropical and subtropical regions throughout the world (Ireland, 1992; O'Shea, 2006; Frey \& Stech, 2009).

\subsection{Lecanorales}

The fossil from Ethiopian amber can confidently be identified as a foliose lichen, which renders it the very first fossil lichen known from Africa. Ethiopian amber is consequently the fourth amber deposit containing lichen in the world, along with the Dominican, Baltic, and Bitterfeld ambers (Kaasalainen et al., 2015, 2017a, 2017b, 2019, 2020; Rikkinen et al., 2018). This underlines the importance of amber as a rich palaeontological material and especially when looking for well-preserved very small cryptogamic specimens.

This article is protected by copyright. All rights reserved. 


\section{Conclusions}

The scarcity of Gondwanan amber deposits compared to those of the Laurasia renders the discovery of the African amber deposit in Ethiopia a new relevant source of information on the Gondwanan history. Furthermore, the Ethiopian amber shows exceptional preservation states of specimens in a very clear amber. Our study confirmed this high fidelity including cellular preservation for cryptogams such as liverworts, mosses and lichens.

The chemical resin composition and angiosperm inclusions in Ethiopian amber indicates Hymenaea (Fabaceae) as the producing tree (Bouju \& Perrichot, 2020), which suggests a tropical environment as for Dominican amber (Heinrichs et al., 2015a). The cryptogamic assemblage reported here from comprises four liverwort species belonging to the extant genera Thysananthus, Lejeunea, and Frullania, a pleurocarpous moss of the extant genus Isopterygium, and a lichen representative of the order Lecanorales. The three liverwort genera from Ethiopian amber are also recorded from coeval Dominican amber, and this Caribbean amber also yields lichens of the order Lecanorales (Rikkinen \& Poinar, 2008; Kaasalainen et al., 2017b). The cryptogam association reported from Dominican amber thus resembles the one from coeval Ethiopian amber and thus suggests similar environmental conditions. Ethiopian amber reveals that these Miocene cryptogam taxa were not restricted to the neotropics. We could, however, not find any evidence of bryophyte species from Ethiopian amber that are identical to those from neotropical ambers at species level, which is likely due to geographical isolation.

Recovery of further bryophytes and lichens from Miocene Ethiopian amber is likely and very promising for understanding the evolution and past distribution of 
bryophytes and lichens, as not even the present distribution of these cryptogams is sufficiently known from the African continent.

\section{Acknowledgments}

We thank Amde Zewdalem (Jacksonville, Florida) and Benyam Teferi (Addis Ababa, Ethiopia) for information on the Ethiopian amber localities and for their invaluable help with the logistics of the field trip in the Amhara Region by V.P. and V.B. in June 2019. We also thank Yale Goldman (Collinsville, Connecticut) for facilitating the access to some of the material studied herein, and for information and contact regarding his amber source. This research was supported by the Tellus-INTERRVIE program of the CNRS INSU (project AMBRAFRICA to V.P.), by the Strategic Priority Research Program of the Chinese Academy of Sciences (XDA19050101 to B.W.) and National Natural Science Foundation of China (41688103 to B.W.), by grant of the mobility program of the EGAAL doctoral school of University of Rennes (to V.B.), and by the German Research Foundation (project 428174246 to K.F., and project 408295270 to U.K.).

\section{References}

Bechteler J, Schäfer-Verwimp A, Lee GE, Feldberg K, Pérez-Escobar OA, Pócs T, Peralta DF, Renner MAM, Heinrichs J. 2017b. Geographical structure, narrow species ranges, and Cenozoic diversification in a pantropical clade of leafy liverworts. Ecology and Evolution 7: 638-653. doi: 10.1002/ece3.2656.

Bechteler J, Schmidt AR, Renner MAM, Wang B, Pérez-Escobar OA, SchäferVerwimp A, Feldberg K, Heinrichs J. 2017a. A Burmese amber fossil of Radula (Porellales, Jungermanniopsida) provides insights into the Cretaceous evolution

This article is protected by copyright. All rights reserved. 
of epiphytic lineages of leafy liverworts. Fossil Record 20: 201-213. doi: $10.5194 /$ fr-20-201-2017.

Berghen CV. 1976. Frullaniaceae (Hepaticae) Africanae. Bulletin du Jardin Botanique National de Belgique: 1-220.

Bombosch A, Wieneke A, Busch A, Jonas R, Hentschel J, Kreier HP, Shaw B, Shaw AJ, Heinrichs J. 2010. Narrow species concepts in the Frullania dilatataappalachiana-eboracensis complex: Evidence from nuclear and chloroplastDNA markers. Plant Systematics and Evolution 290: 151-158. doi: 10.1007/s00606-010-0357-3.

Bouju V, Perrichot V. 2020. A review of amber and copal occurrences in Africa and their paleontological significance. BSGF-Earth Sciences Bulletin 191. doi: $10.1051 / \mathrm{bsgf} / 2020018$.

Carter BE, Larraín J, Manukjanová A, Shaw B, Shaw AJ, Heinrichs J, de Lange P, Suleiman M, Thouvenot L, von Konrat M. 2017. Species delimitation and biogeography of a southern hemisphere liverwort clade, Frullania subgenus Microfrullania (Frullaniaceae, Marchantiophyta). Molecular Phylogenetics and Evolution 107: 16-26. doi: 10.1016/j.ympev.2016.10.002.

Caspary R. 1887. Einige neue Pflanzenreste aus dem samländischen Bernstein. Schriften der Physikalisch-Ökonomischen Gesellschaft zu Königsberg (Abhandlungen) 27: 1-8 (209). Tafel I. „1886“.

Coty D, Lebon M, Nel A. 2016. When phylogeny meets geology and chemistry: doubts on the dating of Ethiopian amber. Ann. Soc. Entomol. Fr. 52: 161-166. doi: $10.1080 / 00379271.2016 .1230477$.

This article is protected by copyright. All rights reserved. 
Dong S, Schäfer-Verwimp A, Meinecke P, Feldberg K, Bombosch A, Pócs T, Schmidt AR, Reitner J, Schneider H, Heinrichs J. 2012. Tramps, narrow endemics and morphologically cryptic species in the epiphyllous liverwort Diplasiolejeunea. Molecular Phylogenetics and Evolution 65: 582-594. doi:

10.1016/j.ympev.2012.07.009.

Dunlop JA. 2010. Bitterfeld amber. In: Penney D ed. Biodiversity of fossils in amber from the major world deposits. Siri Scientific Press, Manchester. 57-68.

Elvebakk A, Elix JA. 2006. Pannaria isidiosa, a new Australian lichen with a new chemosyndrome. The Lichenologist 38: 557-563. doi: $10.1017 / \mathrm{S} 0024282906006141$.

Feldberg K, Gradstein SR, Gröhn C, Heinrichs J, von Konrat M, Mamontov Y, Renner MAM, Roth M, Schäfer-Verwimp A, Sukkharak P, Schmidt AR. 2021a. Checklist of fossil liverworts suitable for calibrating phylogenetic reconstructions. Bryophyte Diversity and Evolution (in press).

Feldberg K, Müller AS, Schäfer-Verwimp A, von Konrat M, Schmidt AR, Heinrichs J. 2018. Frullania grabenhorstii sp. nov., a fossil liverwort (Jungermanniopsida: Frullaniaceae) with perianth from Bitterfeld amber. Bryophyte Diversity and Evolution 40: 91-103. doi: 10.11646/bde.40.2.7.

Feldberg K, Schäfer-Verwimp A, Renner MAM, von Konrat M, Bechteler J, Müller P, Wang YD, Schneider H, Schmidt AR. 2021b. Liverworts from Cretaceous amber. Cretaceous Research (in press).

Feldberg K, Schneider H, Stadler T, Schäfer-Verwimp A, Schmidt AR, Heinrichs J. 2014. Epiphytic leafy liverworts diversified in angiosperm-dominated forests. Scientific Reports 4, 5974. doi: 10.1038/srep05974.

This article is protected by copyright. All rights reserved. 
Feldberg K, Váňa J, Schäfer-Verwimp A, Krings M, Gröhn C, Schmidt AR, Heinrichs J. 2017. Problems related to the taxonomic placement of incompletely preserved amber fossils: transfer of the Paleogene liverwort Cylindrocolea dimorpha (Cephaloziellaceae) to the extant Odontoschisma sect. Iwatsukia (Cephaloziaceae). Fossil Record 20: 147-157. doi: 10.5194/fr-20-147-2017. Frahm JP, Preussing M, Jechorek H. 2007. Laubmoose (Bryophyta, Bryopsida) aus dem Miozän der Oberlausitz (Sachsen, Deutschland). Stuttgarter Beiträge zur Naturkunde (B) 367: 1-23.

Frey W, Stech M. 2009. Division of Bryophyta Schimp. (Musci, Mosses). In: Frey W ed. Syllabus of plant families. Adolf Engler's syllabus der pflanzenfamilien: bryophytes and seedless vascular plants. Gebrüder Borntraeger, Berlin. 116257.

Geological Survey of Ethiopia 1996. Geological map of Ethiopia, second edition. Ministry of Mines.

Gradstein SR. 1993. New fossil hepaticae preserved in amber of the Dominican Republic. Nova Hedwigia 57: 353-374.

Gradstein SR. 2013. A classification of Lejeuneaceae (Marchantiophyta) based on molecular and morphological evidence. Phytotaxa 100: 6-20. doi: 10.11646/phytotaxa.100.1.2.

Grimaldi DA. 1996. Amber: Window to the Past. Harry N. Abrams Inc.

Grolle R. 1980a. Lebermoose im Bernstein 1. Feddes Repertorium 91: 183-190. doi: 10.1002/fedr.19800910304.

Grolle R. 1980b. Lebermoose im Bernstein 2. Feddes Repertorium 91: 401-407. doi: 10.1002/fedr.19800910704.

This article is protected by copyright. All rights reserved. 
Grolle R. 1981a. Was ist Lejeunea schumannii Caspary aus dem Baltischen Bernstein? Occasional Papers of the Fralow Herbarium of Cryptogamic Botany 16: 101-110.

Grolle R. 1981b. Nipponolejeunea fossil in Europa. Journal of the Hattori Botanical Laboratory 50: 143-157.

Grolle R. 1984a. Die Lebermoosgattung Cheilolejeunea fossil in Mitteleuropa. Feddes Repertorium 95: 229-336.

Grolle R. 1984b. Bryopteris und Cyclolejeunea fossil in dominikanischem Bernstein. Journal of the Hattori Botanical Laboratory 56: 271-280.

Grolle R. 1985a. Fossil Spruceanthus in Europe and two other hepatics in Baltic amber. Prace Muzeum Ziemi 37: 79-85.

Grolle R. 1985b. Monograph of Frullania in Baltic amber. Prace Muzeum Ziemi 37: $87-100$.

Grolle R. 1985c. Zwei weitere Lebermoose in Bernstein aus Bitterfeld (DDR). Feddes Repertorium 96: 41-46.

Grolle R. 1987. Radula steerei sp. nov. a further hepatic in Dominican amber. Memoirs of the New York Botanical Garden 45: 259-263.

Grolle R. 1993a. Bryopteris bispinosa spec. nov. (Lejeuneaceae), ein weiteres Lebermoos in dominikanischem Bernstein. Journal of the Hattori Botanical Laboratory 74: 71-76. doi: 10.18968/jhbl.74.0_71.

Grolle R. 1993b. Ein autözisches Lebermoos mit Perianth in dominikanischem Bernstein: Drepanolejeunea eogena spec. nov. Nova Hedwigia 57: 375-380.

Grolle R. 1999. Metacalypogeia (Calypogeiaceae, Hepaticae) new to Europe as Baltic amber fossil. Bryobrothera 5: 87-92.

This article is protected by copyright. All rights reserved. 
Grolle R. 2003. Frullania mammilligera sp. nov., - a new Eocene species of Hepaticae found in Bitterfeld Amber of central Germany. Courier Forschungs-Institut Senckenberg 241: 155-161.

Grolle R, Braune W. 1988. Bazzania oleosa, ein Lebermoos im dominikanischen Bernstein mit erhaltenen Ölkörpern. Beiheft zur Nova Hedwigia 90: 101-108.

Grolle R, Heinrichs J. 2003. Eocene Plagiochila groehnii sp. nov. - the first representative of Plagiochilaceae in Baltic amber. Cryptogamie, Bryologie 24: 189-203.

Grolle R, Meister K. 2004. The liverworts in Baltic and Bitterfeld amber. Weissdorn, Jena.

Grolle R, Schmidt AR. 2001. A fossil Scapania (Hepaticae) with perianth and capsule in Bitterfeld amber (Eocene) from Germany. The Bryologist 104: 362-366. doi: 10.1639/0007-2745(2001)104[0362:AFSHWP]2.0.CO;2.

Grolle R, So ML. 2004. A fossil Porella (Porellaceae, Hepaticae) in Baltic amber (Eocene). Journal of the Linnean Society, Botany 145: 485-488. doi: 10.01111/j.10958339.2004.00291.x.

Grolle R, Zhu R-L, Gradstein SR. 2001. On Cyrtolejeunea A.Evans (Lejeuneaceae, Hepaticae). Taxon 50: 1067-1074. doi: 10.2307/1224721.

Hedenäs L, Watling MC. 2005. Bryophyte flora of Uganda. 5. Hypnaceae (Part 2). Journal of Bryology 27: 153-160. doi: 10.1179/037366805X53077.

Heinrichs J, Feldberg K, Bechteler J, Regalado L, Renner MAM, Schäfer-Verwimp A, Gröhn C, Müller P, Schneider H, Krings M. 2018a. A comprehensive assessment of the fossil record of liverworts in amber. In: Krings M, Cuneo NR, Harper CJ,

This article is protected by copyright. All rights reserved. 
Rothwell GW eds. Transformative paleobotany, papers commemorating the life and legacy of Thomas N. Taylor. Elsevier/Academic. doi: 10.1016/B978-0-12813012-4.00012-7.

Heinrichs J, Hentschel J, Bombosch A, Fiebig A, Reise J, Edelmann M, Kreier HP, Schäfer-Verwimp A, Caspari S, Schmidt AR, Zhu RL, von Konrat M, Shaw B, Shaw AJ. 2010. One species or at least eight? Delimitation and distribution of Frullania tamarisci (L.) Dumort. (Jungermanniopsida, Porellales) inferred from nuclear and chloroplast DNA markers. Molecular Phylogenetics and Evolution 56: 1105-1114. doi: 10.1016/j.ympev.2010.05.004.

Heinrichs J, Kettunen E, Lee GE, Marzaro G, Pócs T, Ragazzi E, Renner MAM, Rikkinen J, Sass-Gyarmati A, Schäfer-Verwimp A, Scheben A, Solórzano Kraemer MM, Svojtka M, Schmidt A. 2015a. Lejeuneaceae (Marchantiophyta) from a species-rich taphocoenosis in Miocene Mexican amber, with a review of liverworts fossilised in amber. Review of Palaeobotany and Palynology 221: 59-70. doi: 10.1016/j.revpalbo.2015.05.007.

Heinrichs J, Reiner-Drehwald ME, Feldberg K, von Konrat M, Hentschel J, Vána J, Nascimbene P, Grimaldi D, Schmidt AR. 2012. The leafy liverwort Frullania (Jungermanniopsida) in the Cretaceous amber forest of Myanmar. Review of Palaeobotany and Palynology 169: 21-28. doi: 10.1016/j.revpalbo.2011.10.002. Heinrichs J, Schäfer-Verwimp A, Boxberger J, Feldberg K, Solórzano Kraemer MM, Schmidt AR. 2014. A fossil species of Ceratolejeunea (Lejeuneaceae, Porellales) preserved in Miocene Mexican amber. The Bryologist 117: 10-14. doi: 10.1639/0007-2745-117.1.010.

This article is protected by copyright. All rights reserved. 
Heinrichs J, Schäfer-Verwimp A, Renner MAM, Feldberg K. 2018b. Cheilolejeunea lamyi sp. nov., a fossil Lejeuneaceae from Miocene Dominican amber.

Cryptogamie, Bryologie 39: 155-161. doi: 10.7872/cryb/v39.iss2.2018.155.

Heinrichs J, Scheben A, Bechteler J, Lee GE, Schäfer-Verwimp A, Hedenäs L, Singh H, Pócs T, Nascimbene PC, Peralta DF, Renner MAM, Schmidt AR. 2016a. Crown group Lejeuneaceae and pleurocarpous mosses in Early Eocene (Ypresian) Indian amber. PLoS One 11, E0156301. doi:

10.1371/journal.pone.0156301.

Heinrichs J, Scheben A, Lee GE, Váňa J, Schäfer-Verwimp A, Krings M, Schmidt AR. 2015b. Molecular and morphological evidence challenges the records of the extant liverwort Ptilidium pulcherrimum in Baltic amber. PloS ONE 10, e140977. doi: 10.1371/journal.pone.0140977.

Heinrichs J, Schmidt AR. 2010. An inclusion of Frullania subgen. Diastoloba s.1. (Frullaniaceae, Porellales) in Dominican amber. Tropical Bryology 31: 91-94. doi: 10.11646/bde.31.1.15.

Heinrichs J, Schmidt AR, Schäfer-Verwimp A, Bauerschmidt L, Neumann C, Gröhn C, Krings M, Renner MAM. 2016b. Revision of the leafy liverwort genus Radula (Porellales, Jungermanniopsida) in Baltic and Bitterfeld amber. Review of Palaeobotany and Palynology 235: 157-164. doi:

10.1016/j.revpalbo.2016.09.004.

Heinrichs J, Schmidt AR, Schäfer-Verwimp A, Gröhn C, Renner MAM. 2015c. The leafy liverwort Notoscyphus balticus spec. nov. (Jungermanniales) in Eocene Baltic amber. Review of Palaeobotany and Palynology 217: 39-44. doi: 10.1016/j.revpalbo.2015.02.006.

This article is protected by copyright. All rights reserved. 
Hentschel J, Schmidt AR, Heinrichs J. 2009b. Frullania cretacea, sp. nov. (Porellales, Jungermanniopsida), a leafy liverwort preserved in Cretaceous amber from Myanmar. Cryptogamie, Bryologie 30: 323-328.

Hentschel J, von Konrat MJ, Pócs T, Schäfer-Verwimp A, Shaw AJ, Schneider H, Heinrichs J. 2009a. Molecular insights into the phylogeny and subgeneric classification of Frullania raddi (Frullaniaceae, Porellales). Molecular Phylogenetics and Evolution 52: 142-156. doi: 10.1016/j.ympev.2008.12.021. Hentschel J, von Konrat M, Söderström L, Hagborg A, Larraín J, Sukkharak P, Uribe J, Zhang L. 2015. Notes on early land plants today. 72. Infrageneric classification and new combinations, new names, news synonyms in Frullania (Marchantiophyta). Phytotaxa 220: 127-142. doi: 10.11646/phytotaxa.220.2.3. Ignatov MS, Perkovsky EE. 2011. Mosses from Rovno amber (Ukraine). Arctoa 20: 1-18. doi: 10.15298/arctoa.20.01.

Ignatov MS, Perkovsky EE. 2013. Mosses from Rovno amber (Ukraine), 2. Arctoa 22: 83-92. doi: 10.15298/arctoa.22.12.

Ireland RR. 1992. The moss genus Isopterygium (Hypnaceae) in Latin America. Tropical Bryology 6: 111-132. doi: 10.11646/bde.6.1.13.

Iturralde-Vinent MA, MacPhee RDE. 2019. Remarks on the age of Dominican amber. Palaeoentomology 2: 236-240. doi: 10.11646/palaeoentomology.2.3.7. Iwatsuki Z, Ramsay HP. 2012. Pylaisiadelphaceae: Isopterygium. Australian Mosses Online 14: 1-3.

Jones EW. 1972. African hepatics XXIII. Some species of Lejeunea. Journal of Bryology 7: 23-45.

This article is protected by copyright. All rights reserved. 
Kaasalainen U, Heinrichs J, Krings M, Myllys L, Grabenhorst H, Rikkinen J, Schmidt AR. 2015. Alectorioid morphologies in Paleogene lichens: new evidence and reevaluation of the fossil Alectoria succini Mägdefrau. PLoS One 10, E0129526. doi: 10.1371/journal.pone.0129526.

Kaasalainen U, Heinrichs J, Renner MAM, Hedenäs L, Schäfer-Verwimp A, Lee GE, Ignatov MS, Rikkinen J, Schmidt AR. 2017b. A Caribbean epiphyte community preserved in Miocene Dominican amber. Earth and Environmental Science Transactions of the Royal Society of Edinburgh 107: 321-331. doi: 10.1017/S175569101700010X.

Kaasalainen U, Kukwa M, Rikkinen J, Schmidt AR. 2019. Crustose lichens with lichenicolous fungi from Paleogene amber. Scientific Reports 9, 10360. doi: 10.1038/s41598-019-46692-w.

Kaasalainen U, Rikkinen J, Schmidt AR. 2020. Fossil Usnea and similar fruticose Lichens from Palaeogene amber. The Lichenologist 52: 319-324. doi: $10.1017 / \mathrm{S} 0024282920000286$.

Kaasalainen U, Schmidt AR, Rikkinen J. 2017a. Diversity and ecological adaptations in Palaeogene lichens. Nature Plants 3, 17049. doi: 10.1038/nplants.2017.49.

Kasiński JR, Kramarska R, Słodkowska B, Sivkov V, Piwocki M. 2020. Paleocene and Eocene deposits on the eastern margin of the Gulf of Gdańsk (Yantarny P-1 borehole, Kaliningrad region, Russia). Geological Quarterly 64: 29-53. doi: 10.7306/gq.1513.

Katagiri T. 2015. First fossil record of the liverwort family Cephaloziaceae (Jungermanniales, Marchantiophyta) from Baltic amber. Nova Hedwigia 101: 347-354. doi: 10.1127/nova_hedwigia/2015/0276.

This article is protected by copyright. All rights reserved. 
Katagiri T. 2018. Geocalyx heinrichsii sp. nov., the first representative of

Geocalycaceae (Jungermanniales, Marchantiophyta) in Baltic amber. Bryophyte Diversity And Evolution 40: 113-117. doi: 10.11646/bde.40.2.9.

Katagiri T, Mukai M, Yamaguchi T. 2013. A new fossil moss Muscites kujiensis (Bryopsida) preserved in the late Cretaceous amber from Japan. The Bryologist 116: 296-301. doi: 10.1639/0007-2745-116.3.296.

Katagiri T, Shinden H. 2020. Discovery of a simple thalloid liverwort Metzgeriites kujiensis (Metzgeriaceae), a new species from Late Cretaceous Japanese amber. Hattoria 11: 13-21. doi: 10.18968/hattoria.11.0_13.

Kettunen E, Sadowski EM, Seyfullah LJ, Dörfelt H, Rikkinen J, Schmidt AR. 2019. Caspary's fungi from Baltic amber: historic specimens and new evidence. Papers In Palaeontology 5: 365-389. doi: 10.1002/spp2.1238.

Kiefert L. 2015. Natural green amber from Ethiopia. 34th International Gemmological Conference, Vilnius, Lithuania. Abstract book. 22-25.

Kistenich S, Bendiksby M, Ekman S, Cáceres MES, Hernández JEM, Timdal E. 2019. Towards an integrative taxonomy of Phyllopsora (Ramalinaceae). The Lichenologist 51: 323-392. doi: 10.1017/S0024282919000252.

Konstantinova NA, Ignatov MS, Perkovsky EE. 2012. Hepatics from Rovno amber (Ukraine). Arctoa 21:265-271. doi: 10.15298/arctoa.21.25.

Lee GE, Bechteler J, Schäfer-Verwimp A, Heinrichs J. 2015b. Microlejeunea miocenica sp. nov. (Porellales, Jungermanniopsida) in Dominican amber, the first fossil of a subcosmopolitan genus of leafy liverworts. Review of Palaeobotany and Palynology 222: 16-21. doi: 10.1016/j.revpalbo.2015.07.002.

This article is protected by copyright. All rights reserved. 
Lee GE, Kolberg L, Bechteler J, Schäfer-Verwimp A, Renner MA, Schmidt AR, Heinrichs J. 2017. The leafy liverwort genus Lejeunea (Porellales, Jungermanniopsida) in Miocene Dominican Amber. Review of Palaeobotany and Palynology 238: 144-150. doi: 10.1016/j.revpalbo.2016.11.013.

Lee GE, Schäfer-Verwimp A, Schmidt AR, Heinrichs J. 2015a. Transfer of the Miocene Lejeunea palaeomexicana Grolle to Ceratolejeunea. Cryptogamie, Bryologie 36: 335-341. doi: 10.7872/cryb/v36.iss4.2015.335.

Lehmann JGC. 1844. I. Novarum et minus cognitarum stirpium pugillus octavus. Meissner, Hamburg.

Li Y, Wang YD, Schneider H, Wu PC. 2020. Frullania partita sp. nov. (Frullaniaceae, Porellales), a new leafy liverwort from the mid-Cretaceous of Myanmar. Cretaceous Research 108, 104341. doi: 10.1016/j.cretres.2019.104341.

Libert MA. 1820. Sur un genre nouveau d'hépatiques, Lejeunia. Annales Générales des Sciences Physiques 6: 372-374.

Lima E, Ilkiu-Borges AL, Gradstein SR. 2020. A new species of Frullania subg. Frullania (Marchantiophyta) from the Brazilian Amazon. Phytotaxa 456: 119124. doi: $10.11646 /$ phytotaxa.456.1.10.

Mamontov YS, Atwood JJ, Perkovsky EE, Ignatov MS. 2020. Hepatics from Rovno amber (Ukraine): Frullania pycnoclada and a new species, F. vanae. The Bryologist 123: 421-430. doi: 10.1639/0007-2745-123.3.421.

Mamontov YS, Heinrichs J, Schäfer-Verwimp A, Ignatov MS, Perkovsky EE. 2013. Hepatics from Rovno amber (Ukraine), 2. Acrolejeunea ucrainica sp. nov. Arctoa 22: 93-96. doi: 10.15298/arctoa.22.13.

This article is protected by copyright. All rights reserved. 
Mamontov YS, Heinrichs J, Schäfer-Verwimp A, Ignatov MS, Perkovsky EE. 2015a.

Hepatics from Rovno amber (Ukraine), 4. Frullania riclefgrollei, sp. nov.

Review of Palaeobotany and Palynology 223: 31-36. doi:

10.1016/j.revpalbo.2015.08.007.

Mamontov YS, Heinrichs J, Váňa J, Ignatov MS, Perkovsky EE. 2015b. Hepatics

from Rovno amber (Ukraine), 3. Anastrophyllum rovnoi sp. nov. Arctoa 24: 43-

46. doi: $10.15298 /$ arctoa.24.08.

Mamontov YS, Heinrichs J, Váňa J, Ignatov MS, Perkovsky EE. 2015c. Hepatics from Rovno amber (Ukraine), 5. Cephaloziella nadezhdae sp. nov. Arctoa 24: 289-293. doi: 10.15298/arctoa.24.25.

Mamontov YS, Hentschel J, Konstantinova NA, Perkovsky EE, Ignatov MS. 2017. Hepatics from Rovno amber (Ukraine), 6. Frullania rovnoi, sp. nov. Journal of Bryology 39, 336-341. doi: 10.1080/03736687.2017.1343220.

Mamontov YS, Ignatov MS, Perkovsky EE. 2018. Hepatics from Rovno amber (Ukraine), 7. Frullania zerovii, sp. nov. Nova Hedwigia 106: 103-113. doi: 10.1127/nova_hedwigia/2017/0446.

Mamontov YS, Ignatov MS, Perkovsky EE. 2019. Liverworts from Rovno amber (Ukraine). 8. Frullania ekaterinae sp. nov. and F. schmalhausenii sp. nov. Paleontological Journal 53: 1095-1103. doi: 10.1134/S0031030119100113. Mitten G. 1869. Musci austro-americani. Journal of the Linnean Society, Botany 12: $1-659$.

O'shea BJ. 2006. Checklist of the mosses of sub-Saharan Africa (Version 5, 12/06). Tropical Bryology Research Reports 6: 1-252.

This article is protected by copyright. All rights reserved. 
Passo A, Calvelo S, Stocker-Wörgötter E. 2004. Taxonomic notes on Pannaria pallida from southern South America and New Zealand. Mycotaxon 90: 355-365.

Penney D, ed. 2010. Biodiversity of fossils in amber from the major world deposits. Siri Scientific Press, Manchester.

Perkovsky EE, Zosimovich VY, Vlaskin AP. 2010. Rovno amber. In: Penney D ed. Biodiversity of fossils in amber from the major world deposits. Siri Scientific Press, Manchester. 116-136.

Perrichot V, Boudinot BE, Chény C, Cole J, Jeanneau L, Schmidt AR, Szwedo J, Wang B. 2018. The age and paleobiota of ethiopian amber revisited. 5th International Paleontological Congress, Paris, France. Abstract book.

Perrichot V, Boudinot BE, Cole J, Delhaye-Prat V, Esnault J, Goldman Y, Nohra YA, Schmidt AR. 2016. African fossiliferous amber: a review. In: Penney D, Ross AJ eds. Abstracts of the 7th International Conference on Fossil Insects, Arthropods and Amber. Siri Scientific Press.

Pócs T. 1996. Epiphyllous liverwort diversity at worldwide level and its threat and conservation. Anales Del Instituto De Biología Serie Botánica, 67: 109-127.

Pócs T, Zhu RL, Reiner-Drehwald E, Söderström L, Hagborg A, von Konrat M. 2015. Notes on early land plants today. 71. New synonyms, new names and new combinations in Lejeuneaceae (Marchantiophyta). Phytotaxa 208: 97-102. doi: 10.11646/phytotaxa.208.1.10.

Potier de la Varde R. 1933-1936. Mousses du Gabon. Mémoires de la Société Nationale des Sciences Naturelles et Mathématiques de Cherbourg 42: 1-270. Raddi G. 1818. Jungermanniografia Etrusca 9. Memoria del Signor Giuseppe Raddi Fiorentino. Atti della Società Italiana delle Scienze in Modena 18: 1-45.

This article is protected by copyright. All rights reserved. 
Ragazzi E, Schmidt AR. 2011. Amber. In: Reitner J, Thiel V eds. Encyclopedia Of Geobiology. Dordrecht, the Netherlands: Springer. 24-35. doi: 10.1007/978-14020-9212-1_9.

Ramaiya M, Johnston MG, Shaw B, Heinrichs J, Hentschel J, von Konrat M, Davison P, Shaw AJ. 2010. Morphologically cryptic biological species within the liverwort Frullania asagrayana. American Journal of Botany 97: 1707-1718. doi: 10.3732/ajb.1000171.

Renauld F, Cardot J. 1915. Histoire naturelle des plantes. Mousses. In: Grandidier A, Grandidier G eds. Histoire physique, naturelle et politique de Madagascar, Paris. 39.

Renner MAM. 2015. Lobule shape evolution in Radula (Jungermanniopsida): one rate fits all? Botanical Journal of the Linnean Society 178: 222-242. doi: 10.1111/boj.12279.

Renner MAM. 2020. Opportunities and challenges presented by cryptic bryophyte species. Telopea 23: 41-60. doi: 10.7751/telopea14083.

Renner MAM, Hesslewood MM, Patzak SDF, Schäfer-Verwimp A, Heinrichs J. 2017. By how much do we underestimate species diversity of liverworts using morphological evidence? An example from Australasian Plagiochila (Plagiochilaceae: Jungermanniopsida). Molecular Phylogenetics Evol. 107: 576-593. doi: 10.1016/j.ympev.2016.12.018.

Rikkinen J, Meinke SKL, Grabenhorst H, Gröhn C, Kobbert M, Wunderlich J, Schmidt AR. 2018. Calicioid lichens and fungi in amber, tracing extant lineages back to the Paleogene. Geobios 51: 469-479. doi: 10.1016/j.geobios.2018.08.009. 
Rikkinen J, Poinar GO. 2008. A new species of Phyllopsora (Lecanorales, lichenforming Ascomycota) from Dominican amber, with remarks on the fossil history of lichens. Journal of Experimental Botany 59: 1007-1011. doi: $10.1093 / \mathrm{jxb} / \mathrm{ern} 004$.

Rikkinen J, Schmidt AR. 2018. Morphological convergence in forest microfungi provides a proxy for paleogene forest structure. In: Krings M, Harper CJ, Cúneo NR, Rothwell GW eds. Transformative palaeobotany. Papers to commemorate the life and legacy of Thomas N. Taylor. New York: Elsevier/Academic Press. 527-549. doi: 10.1016/B978-0-12-813012-4.00022-X.

Rust J, Singh H, Rana RS, McCann T, Singh L, Anderson K, Sarkar N, Nascimbene PC, Stebner F, Thomas JC, Solórzano Kraemer M, Williams CJ, Engel MS, Sahni A, Grimaldi D. 2010. Biogeographic and evolutionary implications of a diverse paleobiota in amber from the early Eocene of India. Proceedings of the National Academy of Sciences of the United States of America 107: 1836018365. doi: 10.1073/pnas. 1007407107.

Sadowski EM, Schmidt AR, Seyfullah LJ, Kunzmann L. 2017. Conifers of the 'Baltic amber forest' and their palaeoecological significance. Stapfia 106: 1-73.

Scheben A, Schmidt AR, Schäfer-Verwimp A, Solórzano Kraemer MM, Heinrichs J. 2014. The first ptychanthoid Lejeuneaceae in Miocene Mexican amber. Telopea 17: 355-361. doi: 10.7751/telopea20148083.

Schiffner V. 1893 Hepaticae. In: Engler A, Prantl K eds. Die Natürlichen Pflanzenfamilien, Teil. I, Abt. 3. Engelmann, Leipzig. 1-144.

Schmidt AR, Jancke S, Lindquist EE, Ragazzi E, Roghi G, Nascimbene P, Schmidt K, Wappler T, Grimaldi DA. 2012. Arthropods in amber from the Triassic Period. 
Proceedings of the National Academy of Sciences USA 109: 14796-14801. doi: 10.1073/pnas. 1208464109.

Schmidt AR, Kaulfuss U, Bannister JM, Baranov V, Beimforde C, Bleile N, Borkent A, Busch A, Conran JG, Engel MS, Harvey M, Kennedy EM, Kerr PH, Kettunen E, Kiecksee AP, Lengeling F, Lindqvist JK, Maraun M, Mildenhall M, Perrichot V, Rikkinen J, Sadowski EM, Seyfullah LJ, Stebner F, Szwedo J, Ulbrich P, Lee DE. 2018. Amber inclusions from New Zealand. Gondwana Research. 56: 135-146. doi: 10.1016/j.gr.2017.12.003

Schmidt AR, Perrichot V, Svojtka M, Anderson KB, Belet KH, Bussert R, Dörfelt H, Jancke S, Mohr B, Mohrmann E, Nascimbene PC, Nel A, Nel P, Ragazzi E, Roghi G, Saupe EE, Schmidt K, Schneider H, Selden PA, Vávra N. 2010. Cretaceous African life captured in amber. Proceedings of the National Academy of Sciences USA 107: 7329-7334. doi: 10.1073/pnas.1000948107.

Schuster RM. 1992. The Hepaticae and Anthocerotae of North America east of the hundredth meridian. Volume V. Field Museum Of Natural History, Chicago.

Serrano-Sánchez M de L, Hegna TA, Schaaf P, Pérez L, Centeno-García E, Vega FJ. 2015. The aquatic and semiaquatic biota in Miocene amber from the Campo LA Granja mine (Chiapas, Mexico): Paleoenvironmental implications. Journal of South American Earth Sciences 62: 243-256. doi:

10.1016/j.jsames.2015.06.007.

Söderström L, Hagborg A, von Konrat M, Bartholomew-Began S, Bell D, Briscoe L, Brown E, Cargill DC, Costa DP, Crandall-Stotler BJ, Cooper ED, Dauphin G, Engel JJ, Feldberg K, Glenny D, Gradstein SR, He X, Heinrichs J, Hentschel J, Ilkiu-Borges AL, Katagiri T, Konstantinova NA, Larraín J, Long DG, Nebel M, 
Pócs T, Puche F, Reiner-Drehwald E, Renner MAM, Sass-Gyarmati A, SchäferVerwimp A, Segarra Moragues JG, Stotler RE, Sukkharak P, Thiers BM, Uribe J, Váňa J, Villarreal JC, Wigginton M, Zhang L, Zhu RL. 2016. World checklist of hornworts and liverworts. PhytoKeys 59: 1-828. doi: 10.3897/phytokeys.59.6261.

Solórzano Kraemer MM. 2010. Mexican amber. In: Penney D ed. Biodiversity of fossils in amber from the major world deposits. Siri Scientific Press, Manchester. 42-56.

Stilwell JD, Langendam A, Mays C, Sutherland LJM, Arillo A, Bickel DJ, De Silva WT, Pentland A, Roghi G, Price GD, Cantrill DJ, Quinney A, Penalver E. 2020. Amber from the Triassic to Paleogene of Australia and New Zealand as exceptional preservation of poorly known terrestrial ecosystems. Scientific Reports 10, 5703. doi: 10.1038/s41598-020-62252-z.

Sukkharak P. 2015. A systematic monograph of the genus Thysananthus (Lejeuneaceae, Marchantiophyta). Phytotaxa 193: 1-81. doi: 10.11646/phytotaxa.193.1.1.

Sukkharak P, Gradstein SR. 2014. A taxonomic revision of the genus Mastigolejeunea (Marchantiophyta: Lejeuneaceae). Nova Hedwigia 99: 279-345. doi: 10.1127/0029-5035/2014/0206.

Sukkharak P, Gradstein SR. 2017. Phylogenetic study of Mastigolejeunea (Marchantiophyta: Lejeuneaceae) and an amended circumscription of the genus Thysananthus. Phytotaxa 326: 91-107. doi: 10.11646/phytotaxa.326.2.1.

Taylor TN, Taylor EL, Krings M. 2009. Paleobotany: the biology and evolution of fossil plants. New-York: Academic Press.

This article is protected by copyright. All rights reserved. 
Tomescu AMF, Bomfleur B, Bippus AC, Savoretti A. 2018. Why are bryophytes so rare in the fossil record? A spotlight on taphonomy and fossil preservation. In: Krings M, Cúneo NR, Harper CJ, Rothwell GW eds. Transformative Paleobotany. Papers to commemorate the life and legacy of Thomas N. Taylor. Elsevier/Academic Press, New York. 375-416. doi: 10.1016/b978-0-12-8130124.00016-4.

Uribe J. 2011. Type studies on Frullania subgenus meteoriopsis. VI. subgeneric affiliation of selected asiatic species previously assigned to subg. Meteoriopsis. Caldasia 33: 67-77.

Váňa J, Schäfer-Verwimp A, Bechteler J, Schmidt AR, Heinrichs J. 2015a. Notoscyphus grollei sp. nov. in Bitterfeld amber rather than the extant Notoscyphus lutescens (Lehm. \& Lindenb.) Mitt. Phytotaxa 222: 151-154. doi: 10.11646/phytotaxa.222.2.8.

Váňa J, Schäfer-Verwimp A, Bechteler J, Schmidt AR, Heinrichs J. 2015b. Transfer of the Eocene Jungermannia berendtii Grolle to Solenostoma. Cryptogamie, Bryologie 36: 285-288. doi: 10.7872/cryb/v36.iss3.2015.285.

Vanderpoorten A, Goffinet B. 2009. Introduction to Bryophytes. Cambridge University Press. doi: 10.1017/CBO9780511626838.

Vanderpoorten A, Gradstein SR, Carine MA, Devos N. 2010. The ghosts of Gondwana and Laurasia in modern liverwort distributions. Biological Reviews 85: 471-487. doi: 10.1111/j.1469-185X.2009.00111.x.

von Konrat M, Hentschel J, Heinrichs J, Braggins JE, Pócs T. 2010. Forty-one degrees below and sixty years in the dark: Frullania sect. Inconditum, a new section of Australasian Frullania species including F. colliculosa, sp. nov. and F.

This article is protected by copyright. All rights reserved. 
hodgsoniae, nom. and stat. nov. Nova Hedwigia 91: 471-500. doi:

10.1127/0029-5035/2010/0091-0471.

von Konrat M, de Lange P, Greif M, Strozier L, Hentschel J, Heinrichs J. 2012.

Frullania knightbridgei, a new liverwort (Frullaniaceae, Marchantiophyta)

species from the deep south of Aotearoa-New Zealand based on an integrated

evidence-based approach. PhytoKeys 8: 13-36. doi: 10.3897/phytokeys.8.2496.

von Konrat M, de Lange P, Larraín J, Hentschel J, Carter B, Shaw J, Shaw B. 2013. A

small world: uncovering hidden diversity in Frullania - a new species from

Aotearoa-New Zealand. Polish Botanical Journal 58: 437-447. doi:

10.2478/pbj-2013-0056.

Wang B, Rust J, Engel MS, Szwedo J, Dutta S, Nel A, Fan Y, Meng F, Shi G, Jarzembowski A, Wappler T, Stebner F, Fang Y, Mao L, Zheng D, Zhang H. 2014. A diverse paleobiota in early Eocene Fushun amber from China. Current Biology 24: 1606-1610. doi: 10.1016/j.cub.2014.05.048.

Wang J, Zhu RL, Gradstein R. 2016. Taxonomic revision of Lejeuneaceae subfamily Ptychanthoideae (Marchantiophyta) in China. Bryophytorum Bibliotheca 65: 1142.

Wigginton MJ. 2004. E.W. Jones's liverwort and hornwort flora of West Africa. Meise: National Botanic Garden.

Wilson R, Heinrichs J, Hentschel J, Gradstein SR, Schneider H. 2007. Steady diversification of derived liverworts under Tertiary climatic fluctuations. Biology Letters 3: 566-569. doi: 10.1098/rsbl.2007.0287.

This article is protected by copyright. All rights reserved. 
Ye W, Zhu R-L. 2010. Leucolejeunea, a new synonym of Cheilolejeunea

(Lejeuneaceae), with special reference to new combinations and nomenclature. Journal of Bryology 32: 279-282. doi: 10.1179/037366810X12814321877507. Yu N-N, Gradstein SR, Narengaowa. 2020. Thysananthus weiweianus N.-N.Yu \& Gradst. (Jungermanniopsida: Lejeuneaceae), a new fossil species in Dominican amber. Chenia 14: 58-62.

Yu Y, Pócs T, Schäfer-Verwimp A, Heinrichs J, Zhu RL, Schneider H. 2013. Evidence for rampant homoplasy in the epiphyllous genus Cololejeunea (Lejeuneaceae). Systematic Botany 38: 553-563. doi: $10.1600 / 036364413 \times 670304$.

Zheng D, Chang SC, Perrichot V, Dutta S, Rudra A, Mu L, Kelly RS, Li S, Zhang Q, Wong J, Wang J, Wang H, Fang Y, Zhang H, Wang B. 2018. A late Cretaceous amber biota from central Myanmar. Nature Communications 9, 3170. doi: $10.1038 / \mathrm{s} 41467-018-05650-2$.

Table 1. Liverwort fossils from Cenozoic amber deposits. Ba: 34-41 Ma, PriabonianLutetian (Eocene), Baltic Region (Sadowski et al., 2017; Kasiński et al., 2020); Bi: 24 Ma, Chattian (late Oligocene), Bernsteinschluff Horizon in the upper part of the Cottbus Formation of the Goitzsche mine, Bitterfeld, Germany (Dunlop, 2010); Do: 15-20 Ma, Burdigalian (middle Miocene), La Toca Formation, Dominican Republic (Penney, 2010; Iturralde-Vinet \& MacPhee 2019); Et: lower Miocene, North Shewa, Ethiopia; In: 52 Ma, Ypresian (lower Eocene), Tadkeshwar Lignite Mine of Gujarat State, India (Cambray amber) (Rust et al., 2010); Mx: 15-23 Ma, Burdigalian (lower Miocene), Simojovel, Chiapas, Mexico (Solórzano Kraemer, 2010; Serrano-Sánchez 
et al., 2015); Uk: 35-37 Ma, Priabonian (late Eocene), amber quarry "Pugach",

Klesov, Ukraine (Rovno amber) (Perkovsky et al., 2010).

\begin{tabular}{|c|c|c|}
\hline Taxon & Deposit & Reference \\
\hline \multicolumn{3}{|l|}{ Jungermanniales } \\
\hline \multicolumn{3}{|l|}{ Anastrophyllaceae } \\
\hline Anastrophyllum rovnoi Mamontov et al. & Uk & $\begin{array}{l}\text { Mamontov et al. 2015b. Arctoa 24: } \\
\text { 45. Figs. 1-6. }\end{array}$ \\
\hline Tetralophozia groehnii Heinrichs et al. & $\mathrm{Ba}$ & $\begin{array}{l}\text { Heinrichs et al. 2015b. PLoS ONE } \\
\text { 10: e0140977. Figs. 2-3. }\end{array}$ \\
\hline \multicolumn{3}{|l|}{ Calypogeiaceae } \\
\hline Calypogeia stenzeliana Grolle & $\mathrm{Bi}$ & $\begin{array}{l}\text { Grolle. 1985c. Feddes Repertorium } \\
\text { 96: 41. Abb. 1a-d, Tafel 1a-c. }\end{array}$ \\
\hline Metacalypogeia baltica Grolle & $\mathrm{Ba}$ & $\begin{array}{l}\text { Grolle. 1999. Bryobrothera 5: } 88 . \\
\text { Figs. 1-2/A-D. }\end{array}$ \\
\hline \multicolumn{3}{|l|}{ Cephaloziaceae } \\
\hline Cephalozia veltenii T.Katag. & $\mathrm{Ba}$ & $\begin{array}{l}\text { Katagiri. 2015. Nova Hedwigia } \\
\text { 101: 347-354. Figs. 1-2. }\end{array}$ \\
\hline $\begin{array}{l}\text { Odontoschisma dimorpha (Casp.) } \\
\text { Heinrichs et al. }\end{array}$ & $\mathrm{Ba}, \mathrm{Bi}$ & $\begin{array}{l}\text { Feldberg et al. 2017. Fossil Record } \\
\text { 20: 151. Figs. 1-2. }\end{array}$ \\
\hline \multicolumn{3}{|l|}{ Cephaloziellaceae } \\
\hline Cephaloziella nadezhdae Mamontov et al. & Uk & $\begin{array}{l}\text { Mamontov et al. 2015b. Arctoa 24: } \\
\text { 293. Figs. 1-8. }\end{array}$ \\
\hline \multicolumn{3}{|l|}{ cf. Cephaloziellaceae } \\
\hline $\begin{array}{l}\text { Protolophozia kutscheri (Grolle) Heinrichs } \\
\text { et al. }\end{array}$ & $\mathrm{Ba}, \mathrm{Bi}$ & $\begin{array}{l}\text { Feldberg et al. 2021a. Bryophyte } \\
\text { Diversity \& Evolution (in press). }\end{array}$ \\
\hline \multicolumn{3}{|l|}{ Geocalycaceae } \\
\hline Geocalyx heinrichsii T.Katag. & $\mathrm{Ba}$ & Katagiri. 2018. Bryophyte Diversity \\
\hline
\end{tabular}

This article is protected by copyright. All rights reserved. 
and Evolution 40: 113. Fig. 1.

\section{Lepidoziaceae}

Bazzania oleosa Grolle

Do

Grolle. 1988. Beiheft zur Nova

Hedwigia 90: 102. Abb. 1, Taf. I-

III.

Bazzania polyodus (Casp.) Grolle $\quad$ Ba, Bi $\quad$ Grolle. 1980a. Feddes Repertorium

$\begin{array}{ll}91: 188 . \text { Abb. 1/g-k, Tafel 15- } \\ 16 / \mathrm{a}-\mathrm{b} .\end{array}$

\section{Nothoscyphaceae}

Nothoscyphus balticus Heinrichs et al. $\quad \mathrm{Ba} \quad$ Heinrichs et al. 2015c. Review of Palaeobotany and Palynology 217: 40. Plates I-II.

Nothoscyphus grollei Váňa et al.

$\mathrm{Bi}$

Váňa et al. 2015a. Phytotaxa 222: 153. Fig. 1.

\section{Plagiochilaceae}

Plagiochila groehnii Grolle \& Heinrichs Ba Grolle \& Heinrichs. 2003.

Cryptogamie Bryologie 24: 189.

Figs. 1-2.

\section{Scapaniaceae}

Scapania hoffeinsiana Grolle

Ba, Bi Grolle \& Schmidt. 2001. The

Bryologist 104: 362. Figs. 1-10.

\section{Solenostomataceae}

Solenostoma berendtii (Grolle) Váňa et al. Ba Ván̆a et al. 2015b. Cryptogamie Bryologie 36: 287. Figs. 1-3.

\section{Porellales}

\section{Frullaniaceae}

Frullania acutata Casp.

$\mathrm{Ba}$

Caspary. 1887. Schriften der

Physikalisch-Ökonomischen

Gesellschaft zu Königsberg 27: 5.

Tafel 1 Bild 23.

This article is protected by copyright. All rights reserved. 


\begin{tabular}{|c|c|c|}
\hline Frullania baltica Grolle & $\mathrm{Ba}, \mathrm{Bi}$ & $\begin{array}{l}\text { Grolle. 1985b. Prace Muzeum } \\
\text { Ziemi 37: 89. Plate 1, Figs. 1a-b. }\end{array}$ \\
\hline Frullania casparyi Grolle & $\mathrm{Ba}, \mathrm{Bi}$ & $\begin{array}{l}\text { Grolle. 1985b. Prace Muzeum } \\
\text { Ziemi 37: 92. Plate 3, Figs. 2e-I. } \\
\text { 1985. }\end{array}$ \\
\hline Frullania ekaterinae Mamontov et al. & Uk & $\begin{array}{l}\text { Mamontov et al. } 2019 . \\
\text { Paleontological Journal 53: } 1096 . \\
\text { Figs. 1, 3a, d-f, h-i. }\end{array}$ \\
\hline Frullania grabenhorstii Heinrichs et al. & $\mathrm{Bi}$ & $\begin{array}{l}\text { Feldberg et al. 2018. Bryophyte } \\
\text { Diversity \& Evolution 40: 94. Figs. } \\
\text { 1-2. } 2018 .\end{array}$ \\
\hline Frullania mammilligera Grolle & $\mathrm{Bi}$ & $\begin{array}{l}\text { Grolle. 2003. Courier } \\
\text { Forschungsinstitut Senckenberg } \\
\text { 241: 155. Plates 1-2. }\end{array}$ \\
\hline $\begin{array}{l}\text { Frullania palaeoafricana Feldberg et al., } \\
\text { sp. nov. }\end{array}$ & Et & this paper \\
\hline Frullania pycnoclada Grolle & $\mathrm{Ba}$ & $\begin{array}{l}\text { Grolle \& Meister. 2004. The } \\
\text { Liverworts in Baltic and Bitterfeld } \\
\text { Amber: } 22 . \text { Plate } 9 / 10 \mathrm{a}-\mathrm{c} .\end{array}$ \\
\hline Frullania riclefgrollei Mamontov et al. & Uk & $\begin{array}{l}\text { Mamontov et al. 2015a. Review of } \\
\text { Palaeobotany and Palynology } 223 \\
\text { 32. Plates I-II. }\end{array}$ \\
\hline Frullania rovnoi Mamontov et al. & $\mathrm{Uk}$ & $\begin{array}{l}\text { Mamontov et al. 2017. Journal of } \\
\text { Bryology 39: 337. Figs. 1-2. }\end{array}$ \\
\hline Frullania schmalhausenii Mamontov et al. & Uk & $\begin{array}{l}\text { Mamontov et al. } 2019 . \\
\text { Paleontological Journal 53: } 1100 . \\
\text { Figs. 2, 3b, c, g, j, k. }\end{array}$ \\
\hline Frullania schumannii (Casp.) Grolle & $\mathrm{Ba}, \mathrm{Bi}$ & Grolle. 1981a. Occasional Papers \\
\hline
\end{tabular}

This article is protected by copyright. All rights reserved. 


\begin{tabular}{|c|c|c|}
\hline & & $\begin{array}{l}\text { of the Farlow Herbarium of } \\
\text { Cryptogamic Botany 16: 102. Figs. } \\
\text { 1-5. }\end{array}$ \\
\hline $\begin{array}{l}\text { Frullania shewanensis Feldberg et al., sp. } \\
\text { nov. }\end{array}$ & Et & this paper \\
\hline Frullania truncata Casp. & $\mathrm{Ba}, \mathrm{Bi}$ & $\begin{array}{l}\text { Caspary. 1887. Schriften der } \\
\text { Physikalisch-Ökonomischen } \\
\text { Gesellschaft zu Königsberg 27: } 4 . \\
\text { Tafel } 1 \text { Bild } 16 .\end{array}$ \\
\hline Frullania varians Casp. & $\begin{array}{l}\mathrm{Uk}, \mathrm{Ba} \\
\mathrm{Bi}\end{array}$ & $\begin{array}{l}\text { Caspary. 1887. Schriften der } \\
\text { Physikalisch-Ökonomischen } \\
\text { Gesellschaft zu Königsberg 27: } 5 . \\
\text { Tafel } 1 \text { Bild } 17-18 \text { as } F \text {. varians, } \\
\text { Tafel } 1 \text { Bild } 29-30 \text { as } F \text {. } \\
\text { magniloba. }\end{array}$ \\
\hline Frullania vanae Mamontov et al. & Uk & $\begin{array}{l}\text { Mamontov et al. 2020. The } \\
\text { Bryologist } 123 .\end{array}$ \\
\hline Frullania zerovii Mamontov et al. & Uk & $\begin{array}{l}\text { Mamontov et al. 2018. Nova } \\
\text { Hedwigia 106: 104. Figs. 1-13. }\end{array}$ \\
\hline \multicolumn{3}{|l|}{ cf. Frullaniaceae/ Lepidolaenaceae } \\
\hline $\begin{array}{l}\text { Pseudofrullania hamatosetacea (Grolle) } \\
\text { Heinrichs et al. }\end{array}$ & $\mathrm{Bi}$ & $\begin{array}{l}\text { Heinrichs et al. 2018a. A } \\
\text { Comprehensive Assessment of the } \\
\text { Fossil Record of Liverworts in } \\
\text { Amber. In Krings et al. eds. } \\
\text { Transformative Paleobotany. } \\
\text { Papers Commemorating the Life } \\
\text { and Legacy of Thomas N. Taylor. } \\
\text { 225. Plate III(5-7). }\end{array}$ \\
\hline \multicolumn{3}{|l|}{ Jubulaceae } \\
\hline Nipponolejeunea europaea Grolle & $\mathrm{Ba}, \mathrm{Bi}$ & $\begin{array}{l}\text { Grolle. 1981b. Journal of the } \\
\text { Hattori Botanical Laboratory 50: } \\
\text { 146. Abb. 3a-g, Tafel 3-6. }\end{array}$ \\
\hline
\end{tabular}

This article is protected by copyright. All rights reserved. 


\begin{tabular}{|c|c|c|}
\hline Lejeuneaceae & & \\
\hline Acrolejeunea ucrainica Mamontov et al. & Uk & $\begin{array}{l}\text { Mamontov et al. 2013. Arctoa 22: } \\
\text { 95. Figs. } 1-10 .\end{array}$ \\
\hline Blepharolejeunea obovata Gradst. & Do & $\begin{array}{l}\text { Gradstein. 1993. Nova Hedwigia } \\
\text { 57: 357. Fig. } 2 \text {. }\end{array}$ \\
\hline Bryopteris bispinosa Grolle & Do & $\begin{array}{l}\text { Grolle. 1993a. Journal of the } \\
\text { Hattori Botanical Laboratory } 74 \text { : } \\
\text { 73. Abb. 1-2. }\end{array}$ \\
\hline Bryopteris succinea Grolle & Do & $\begin{array}{l}\text { Grolle. 1984b. Journal of the } \\
\text { Hattori Botanical Laboratory 56: } \\
\text { 271. Abb. 1/A-D, Taf. 1-2. }\end{array}$ \\
\hline Ceratolejeunea antiqua Heinrichs et al. & $\mathrm{Me}$ & $\begin{array}{l}\text { Heinrichs et al. 2014. The } \\
\text { Bryologist 117: 11. 2014. Figs. 1-2. }\end{array}$ \\
\hline $\begin{array}{l}\text { Ceratolejeunea palaeomexicana (Grolle) } \\
\text { G.E.Lee et al. }\end{array}$ & $\mathrm{Me}$ & $\begin{array}{l}\text { Lee et al. 2015a. Cryptogamie, } \\
\text { Bryologie 36: 339. Figs. 1-7. }\end{array}$ \\
\hline $\begin{array}{l}\text { Ceratolejeunea sublaetefusca Heinrichs et } \\
\text { al. }\end{array}$ & $\mathrm{Me}$ & $\begin{array}{l}\text { Heinrichs et al. 2015a. Review of } \\
\text { Palaeobotany and Palynology 221: } \\
\text { 62. Plate III. }\end{array}$ \\
\hline Ceratolejeunea spec. & Do & $\begin{array}{l}\text { Gradstein. 1993. Nova Hedwigia } \\
57 .\end{array}$ \\
\hline $\begin{array}{l}\text { Cheilolejeunea antiqua (Grolle) W.Ye \& } \\
\text { R.L.Zhu }\end{array}$ & Do & $\begin{array}{l}\text { Ye \& Zhu. 2010. Journal of } \\
\text { Bryology 32: } 280 .\end{array}$ \\
\hline Cheilolejeunea lamyi Heinrichs et al. & Do & $\begin{array}{l}\text { Heinrichs et al. } 2018 \mathrm{~b} . \\
\text { Cryptogamie, Bryologie 39: } 156 . \\
\text { Figs. 1-8. }\end{array}$ \\
\hline Cheilolejeunea latiloba (Casp.) Grolle & $\mathrm{Ba}, \mathrm{Bi}$ & $\begin{array}{l}\text { Grolle. 1984a. Feddes Repertorium } \\
\text { 95: 230. Abb.1, Tafel 31-36. }\end{array}$ \\
\hline
\end{tabular}

This article is protected by copyright. All rights reserved. 


\begin{tabular}{|c|c|c|}
\hline $\begin{array}{l}\text { Cheilolejeunea suzannensis (Grolle) } \\
\text { Grolle \& R.L.Zhu }\end{array}$ & Do & $\begin{array}{l}\text { Grolle \& Zhu. 2001. Taxon 50: } \\
1073 .\end{array}$ \\
\hline Cololejeunea spec. & Do & $\begin{array}{l}\text { Rikkinen \& Poinar. 2008. Journal } \\
\text { of Experimental Botany } 59 .\end{array}$ \\
\hline Cyclolejeunea archaica Grolle & Do & $\begin{array}{l}\text { Grolle. 1984b. Journal of the } \\
\text { Hattori Botanical Laboratory 56: } \\
\text { 274. Abb. 1/E-G, Taf. 4-5. }\end{array}$ \\
\hline Dibrachiella grollei (Gradst.) Gradst. & Do & $\begin{array}{l}\text { Feldberg et al. 2021. Bryophyte } \\
\text { Diversity \& Evolution (in press). }\end{array}$ \\
\hline Drepanolejeunea eogena Grolle & Do & $\begin{array}{l}\text { Grolle. 1993b. Nova Hedwigia 57: } \\
\text { 376. Figs. 1-2. }\end{array}$ \\
\hline $\begin{array}{l}\text { Lejeunea abyssinicoides Schäf.-Verw.et } \\
\text { al., sp. nov. }\end{array}$ & Et & this paper \\
\hline Lejeunea hamatiloba G.E.Lee et al. & Do & $\begin{array}{l}\text { Lee et al. 2017. Review of } \\
\text { Palaeobotany and Palynology 238: } \\
\text { 147. Plates I.1, II.1-2, Fig. } 1 .\end{array}$ \\
\hline Lejeunea miocenica Heinrichs et al. & Do & $\begin{array}{l}\text { Kaasalainen et al. } 2017 \mathrm{~b} \text {. Earth and } \\
\text { Environmental Science } \\
\text { Transactions of the Royal Society } \\
\text { of Edinburgh 107: 323. Figs. 1B, } 3 .\end{array}$ \\
\hline Lejeunea resinata G.E.Lee et al. & Do & $\begin{array}{l}\text { Lee et al. 2017. Review of } \\
\text { Palaeobotany and Palynology 238: } \\
\text { 147. Plates I.2, II.3-4, Fig. } 2 .\end{array}$ \\
\hline Lejeunea urbanioides G.E.Lee et al. & Do & $\begin{array}{l}\text { Lee et al. 2017. Review of } \\
\text { Palaeobotany and Palynology 238: } \\
\text { 147. Plates I.2, II.3-4, Fig. } 2 .\end{array}$ \\
\hline Lopholejeunea subnigricans Gradst. & Do & $\begin{array}{l}\text { Gradstein. 1993. Nova Hedwigia } \\
\text { 57: 359. Fig. } 4 .\end{array}$ \\
\hline
\end{tabular}

This article is protected by copyright. All rights reserved. 


\begin{tabular}{|c|c|c|}
\hline $\begin{array}{l}\text { Marchesinia brachiata }(\mathrm{Sw} .) \\
\text { V.F.Schiffner }\end{array}$ & $\begin{array}{l}\text { Do, } \\
\text { extant }\end{array}$ & $\begin{array}{l}\text { Schiffner. 1893. In Engler \& Prantl } \\
\text { eds. Die Natürliche } \\
\text { Pflanzenfamilien 1, 3: } 128 . \\
\text { Cf. Gradstein. 1993. Nova } \\
\text { Hedwigia 57. }\end{array}$ \\
\hline Marchesinia pusilla Gradst. & Do & $\begin{array}{l}\text { Gradstein. 1993. Nova Hedwigia } \\
\text { 57: 362. Fig. } 6 .\end{array}$ \\
\hline Microlejeunea miocenica G.E.Lee et al. & Do & $\begin{array}{l}\text { Lee et al. 2015b. Review of } \\
\text { Palaeobotany and Palynology 222: } \\
\text { 17. Plates I-II. }\end{array}$ \\
\hline Microlejeunea nyiahae Heinrichs et al. & In & $\begin{array}{l}\text { Heinrichs et al. 2016a. PLoS ONE } \\
\text { 11(5): e0156301: 5/15. Figs. 1A, } 2- \\
\text { 3. }\end{array}$ \\
\hline Neurolejeunea macrostipula Gradst. & Do & $\begin{array}{l}\text { Gradstein. 1993. Nova Hedwigia } \\
\text { 57: 368. Fig. } 9 .\end{array}$ \\
\hline $\begin{array}{l}\text { Spruceanthus extinctus (Heinrichs et al.) } \\
\text { Gradst. \& Sukkharak }\end{array}$ & $\mathrm{Me}$ & $\begin{array}{l}\text { Feldberg et al. 2021. Bryophyte } \\
\text { Diversity \& Evolution (in press). }\end{array}$ \\
\hline Spruceanthus polonicus Grolle & $\mathrm{Ba}$ & $\begin{array}{l}\text { Grolle. 1985a. Prace Museum } \\
\text { Ziemi 37: 79. Plate 1-2. Fig. } 1 .\end{array}$ \\
\hline $\begin{array}{l}\text { Stictolejeunea squamata (Willd.) } \\
\text { V.F.Schiffner }\end{array}$ & $\begin{array}{l}\text { Do, } \\
\text { extant }\end{array}$ & $\begin{array}{l}\text { Schiffner. 1893. In Engler \& Prantl } \\
\text { eds. Die Natürlichen } \\
\text { Pflanzenfamilien 1, 3: } 133 \text {. } \\
\text { Gradstein. 1993. Nova Hedwigia } 57\end{array}$ \\
\hline $\begin{array}{l}\text { Thysananthus aethiopicus Bouju et al., sp. } \\
\text { nov. }\end{array}$ & Et & this paper \\
\hline $\begin{array}{l}\text { Thysananthus auriculatus (Wils.) } \\
\text { Sukkharak \& Gradst. }\end{array}$ & Do & $\begin{array}{l}\text { Sukkharak \& Gradstein. } 2017 . \\
\text { Phytotaxa 326: 102. } \\
\text { Gradstein. 1993. Nova Hedwigia } 57\end{array}$ \\
\hline Thysananthus bidentulus (Gradst.) & Do & Sukkharak \& Gradstein. 2017. \\
\hline
\end{tabular}

This article is protected by copyright. All rights reserved. 


\begin{tabular}{|c|c|c|}
\hline Sukkharak \& Gradst. & & Phytotaxa 326: 103. \\
\hline $\begin{array}{l}\text { Thysananthus contortus (Göpp. \& } \\
\text { Berendt) Sukkharak \& Gradst. }\end{array}$ & $\mathrm{Ba}, \mathrm{Bi}$ & $\begin{array}{l}\text { Sukkharak \& Gradstein. } 2017 . \\
\text { Phytotaxa 326: } 103 .\end{array}$ \\
\hline $\begin{array}{l}\text { Thysananthus weiweianus N.-N.Yu \& } \\
\text { Gradst. }\end{array}$ & Do & Yu et al. 2020. Chenia 14. \\
\hline \multicolumn{3}{|l|}{ Porellaceae } \\
\hline Porella subgrandiloba Grolle \& M.L.So & $\mathrm{Ba}$ & $\begin{array}{l}\text { Grolle \& So. 2004. Journal of the } \\
\text { Linnean Society, Botany 145: } 485 . \\
\text { Figs. } 2-4 .\end{array}$ \\
\hline \multicolumn{3}{|l|}{ Radulaceae } \\
\hline Radula baltica Heinrichs et al. & $\mathrm{Ba}$ & $\begin{array}{l}\text { Heinrichs et al. 2016b. Review of } \\
\text { Palaeobotany and Palynology } 235 \text { : } \\
\text { 158. Plate I. }\end{array}$ \\
\hline Radula intecta M.A.M.Renner et al. & Do & $\begin{array}{l}\text { Kaasalainen et al. 2017b. Earth and } \\
\text { Environmental Science } \\
\text { Transactions of the Royal Society } \\
\text { of Edinburgh 107: } 324 \text {. Fig. } 4 .\end{array}$ \\
\hline Radula oblongifolia Casp. & $\mathrm{Ba}, \mathrm{Bi}$ & $\begin{array}{l}\text { Caspary. 1887. Schriften der } \\
\text { Physikalisch-Ökonomischen } \\
\text { Gesellschaft zu Königsberg 27: } 4 .\end{array}$ \\
\hline Radula sphaerocarpoides Grolle & $\mathrm{Ba}, \mathrm{Bi}$ & $\begin{array}{l}\text { Grolle. 1980b. Feddes Repertorium } \\
\text { 91: } 404 .\end{array}$ \\
\hline Radula steerei Grolle & Do & $\begin{array}{l}\text { Grolle. 1987. Memoirs of the New } \\
\text { York Botanical Garden 45: } 259 . \\
\text { Figs. 1-3. }\end{array}$ \\
\hline \multicolumn{3}{|l|}{ Ptilidiales } \\
\hline Ptilidium spec. & $\mathrm{Ba}$ & $\begin{array}{l}\text { Heinrichs et al. 2015b. PLOS ONE } \\
\text { 10: e140977. }\end{array}$ \\
\hline
\end{tabular}

This article is protected by copyright. All rights reserved. 
Table 2. List of studied material. h: holotype; Asterisks $\square$ indicate specimens that were originally preserved as syninclusions in a single amber piece but have been separated in multiple amber fragments for study.

\begin{tabular}{|c|c|c|c|}
\hline Collection number \# & Taxon & Associated insects & Figures \\
\hline PB23742 * & Thysananthus aethiopicus (h) & & 3A-E \\
\hline PB23742 * & Lecanorales & & 9 \\
\hline PB23743* & Thysananthus aethiopicus & $\begin{array}{l}\text { Melissotarsus (Formicidae) } \\
\text { Trichomyrmex (Formicidae) }\end{array}$ & $3 \mathrm{~F}, \mathrm{G}$ \\
\hline \multirow{3}{*}{ IGR.ET2020/009 } & Isopterygium $\mathrm{sp}$. & & $1 \mathrm{~A}, \mathrm{~B}$ \\
\hline & Frullania shewanensis & & $\begin{array}{l}1 \mathrm{~A}, \mathrm{~B} \\
6\end{array}$ \\
\hline & Lejeunea abyssinicoides $(\mathrm{h})$ & & $\begin{array}{l}1 \mathrm{~A}, \mathrm{~B} \\
4\end{array}$ \\
\hline IGR.ET2020/010 & Thysananthus aethiopicus & & $3 \mathrm{H}, \mathrm{I}$ \\
\hline IGR.ET2020/011 & Isopterygium sp. & & 8 \\
\hline IGR.ET2020/012 & Thysananthus aethiopicus & $\begin{array}{l}\text { Hymenoptera } \\
\text { Psychodidae (Diptera) } \\
\text { Cecidomyiidae (Diptera) }\end{array}$ & $1 \mathrm{C}$ \\
\hline IGR.ET2020/013b & Frullania shewanensis $(\mathrm{h})$ & Coleoptera & 5 \\
\hline IGR.ET2020/015 & Frullania palaeoafricana $(\mathrm{h})$ & & 7 \\
\hline
\end{tabular}

\section{Figures captions}

This article is protected by copyright. All rights reserved. 

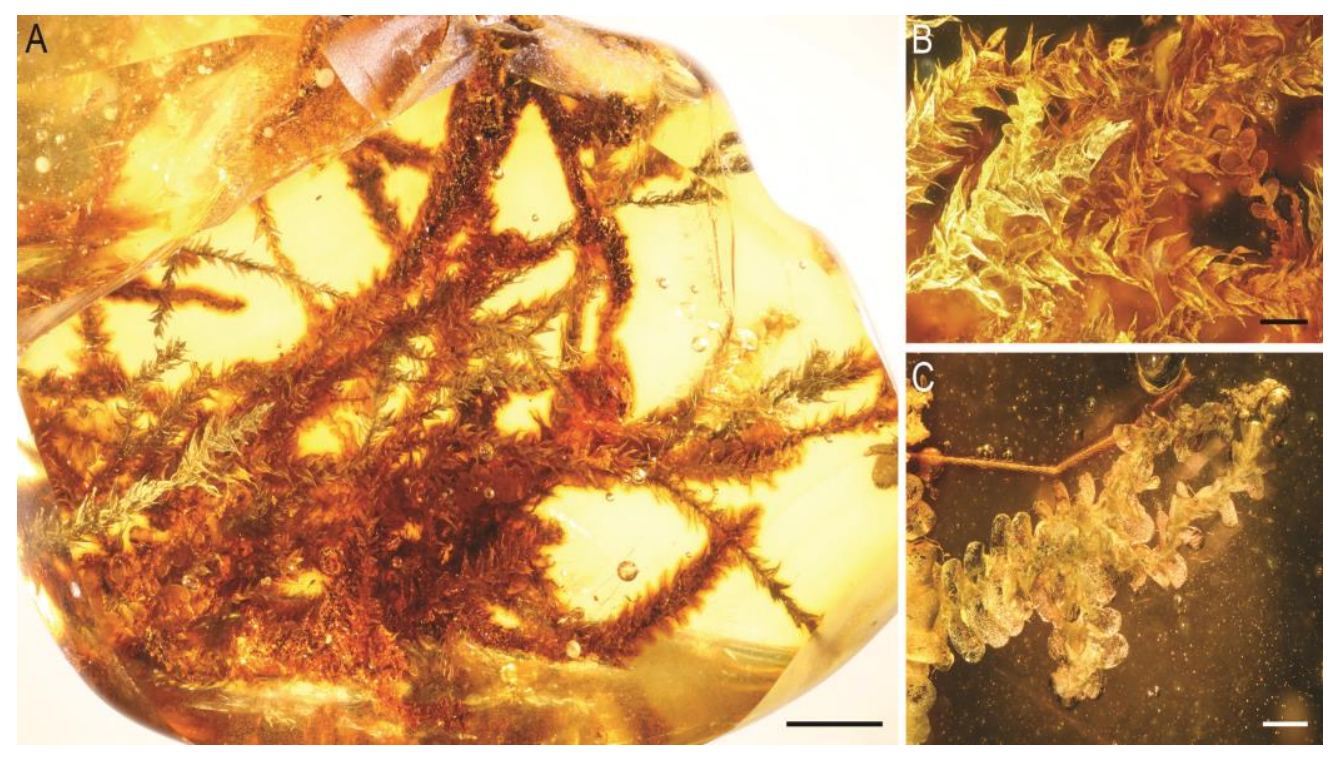

Fig. 1. A, Community of Bryophyta (Isopterygium sp.) and Marchantiophyta

(Frullania shewanensis sp. nov., Lejeunea abyssinicoides sp. nov.) from Miocene

Ethiopian amber (IGR.ET2020/009). B, Detail of(A) showing two shoots of Lejeunea abyssinicoides within densely growing Isopterygium sp. C, Dorsal overview of a gametophyte of Thysananthus aethiopicus sp. nov., (IGR.ET2020/012). Scale bars: A $=2 \mathrm{~mm}, \mathbf{B}=300 \mu \mathrm{m}, \mathbf{C}=500 \mu \mathrm{m}$.

This article is protected by copyright. All rights reserved. 


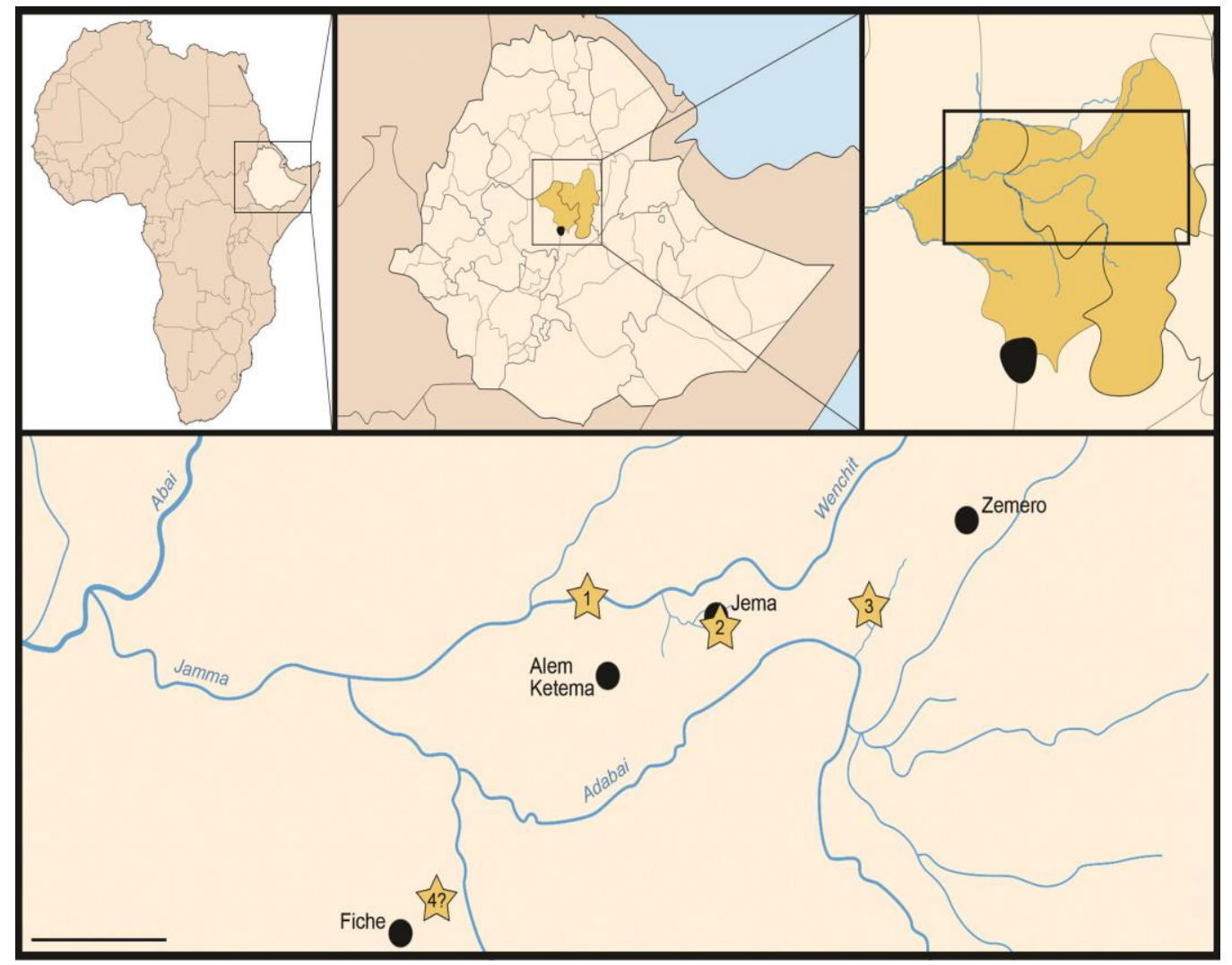

Fig. 2. Geographical maps showing the location of amber outcrops in Ethiopia (Geological Survey of Ethiopia, 1996). Amhara Region, North Shewa Zone: 1, Alem

Ketema (from Schmidt et al., 2010); 2, Jema, near Merany (from Coty et al., 2016); 3, Woll, east of Zemero (from Bouju \& Perrichot, 2020). Oromia Region, North Shewa Zone: 4, precise locality unknown near the town of Fiche, (unpublished pers. data). Scale bar $=20 \mathrm{~km}$

This article is protected by copyright. All rights reserved. 

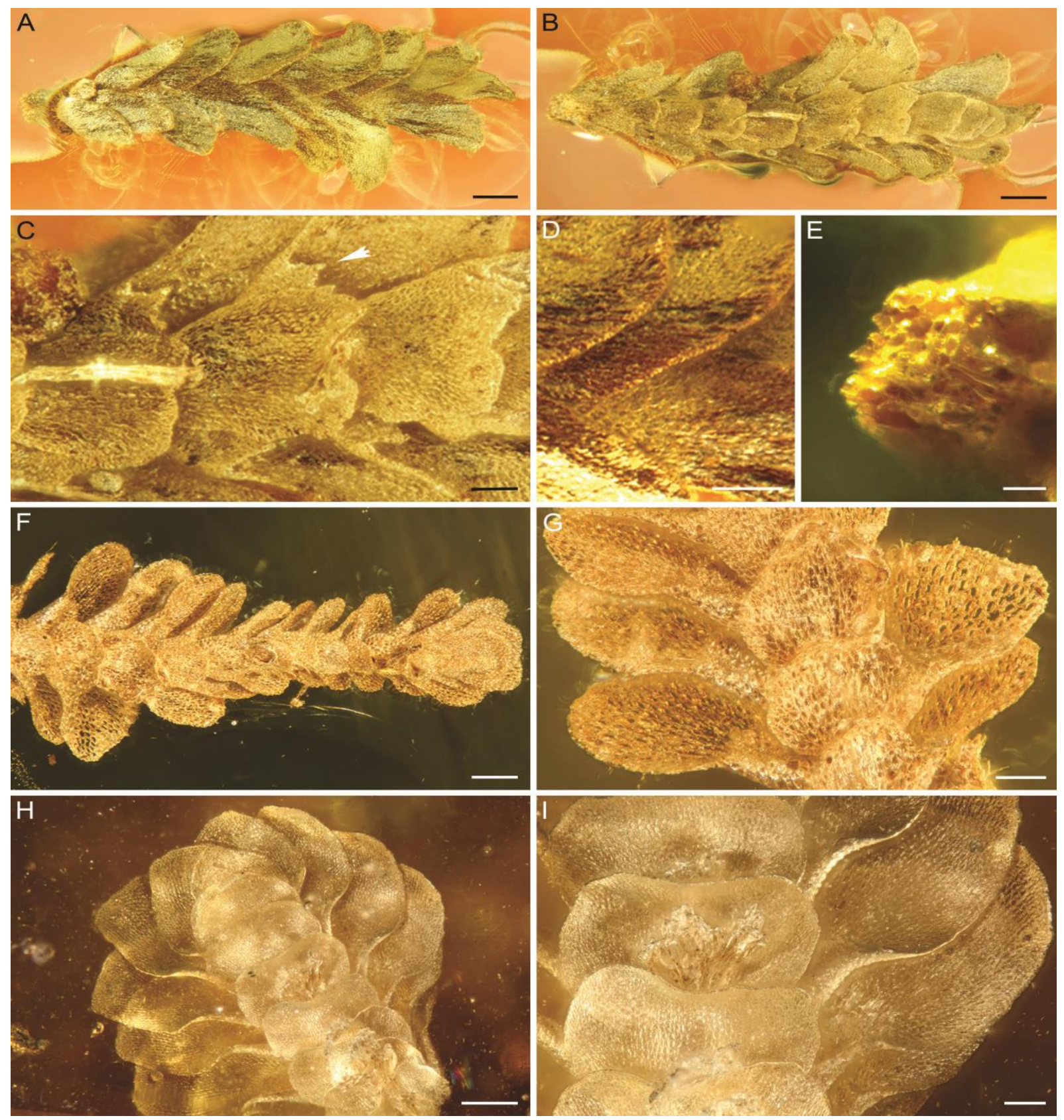

Fig. 3. Thysananthus aethiopicus sp. nov. from Miocene Ethiopian amber. A-E, holotype PB23742. A, Gametophyte in dorsal view. B, Gametophyte in ventral view. C, Leaf lobules (arrow) and underleaves in ventral view. D, Leaf lobes in dorsal view. E, Stem cross section at base of shoot. F-G, PB23743. F, Gametophyte in ventral view. G, Leaf lobes, lobules, and underleaves in ventral view. H-I, IGR.ET2020/010. $\mathbf{H}$, Gametophyte in ventral view. I, Leaf lobes, lobules, and underleaves in ventral

This article is protected by copyright. All rights reserved. 
view. Scale bars: $\mathbf{A}, \mathbf{B}, \mathbf{F}=0.15 \mathrm{~mm}, \mathbf{C}, \mathbf{D}=0.05 \mathrm{~mm}, \mathbf{E}=0.02 \mathrm{~mm}, \mathbf{G}, \mathbf{I}=0.10 \mathrm{~mm}$, $\mathbf{H}=0.3 \mathrm{~mm}$.
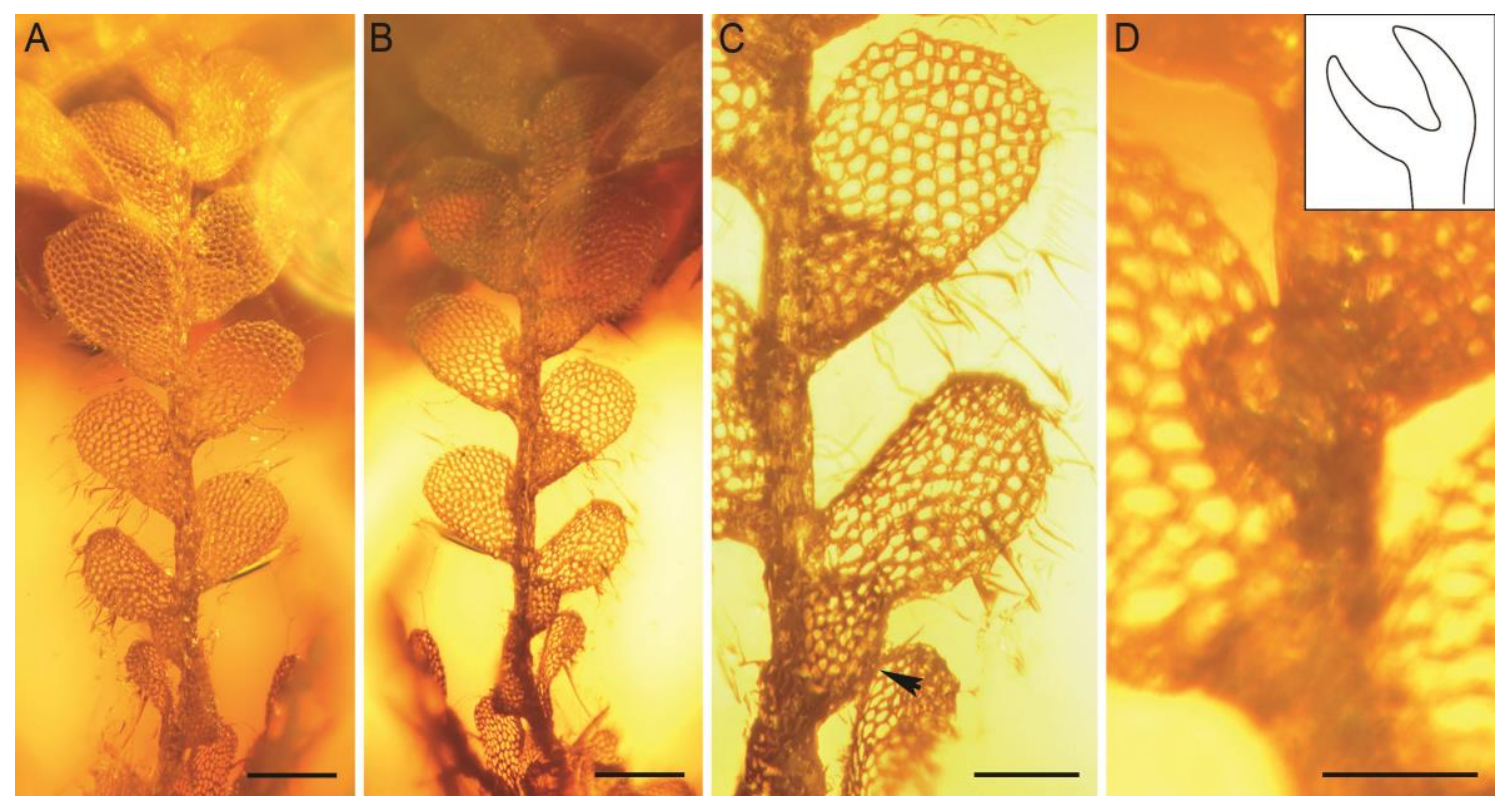

Fig. 4. Lejeunea abyssinicoides sp. nov. from Miocene Ethiopian amber, holotype IGR.ET2020/009. A, Gametophyte in dorsal view. B, Gametophyte in ventral view. C, Lobes and lobules (one lobule indicated by an arrow) in ventral view. D, Underleaf visible in the middle of the image; the outline in the upper right emphasizes its shape. Scale bars: A, $\mathbf{B}=0.15 \mathrm{~mm}, \mathbf{C}=0.07 \mathrm{~mm}, \mathbf{D}=0.05 \mathrm{~mm}$. 

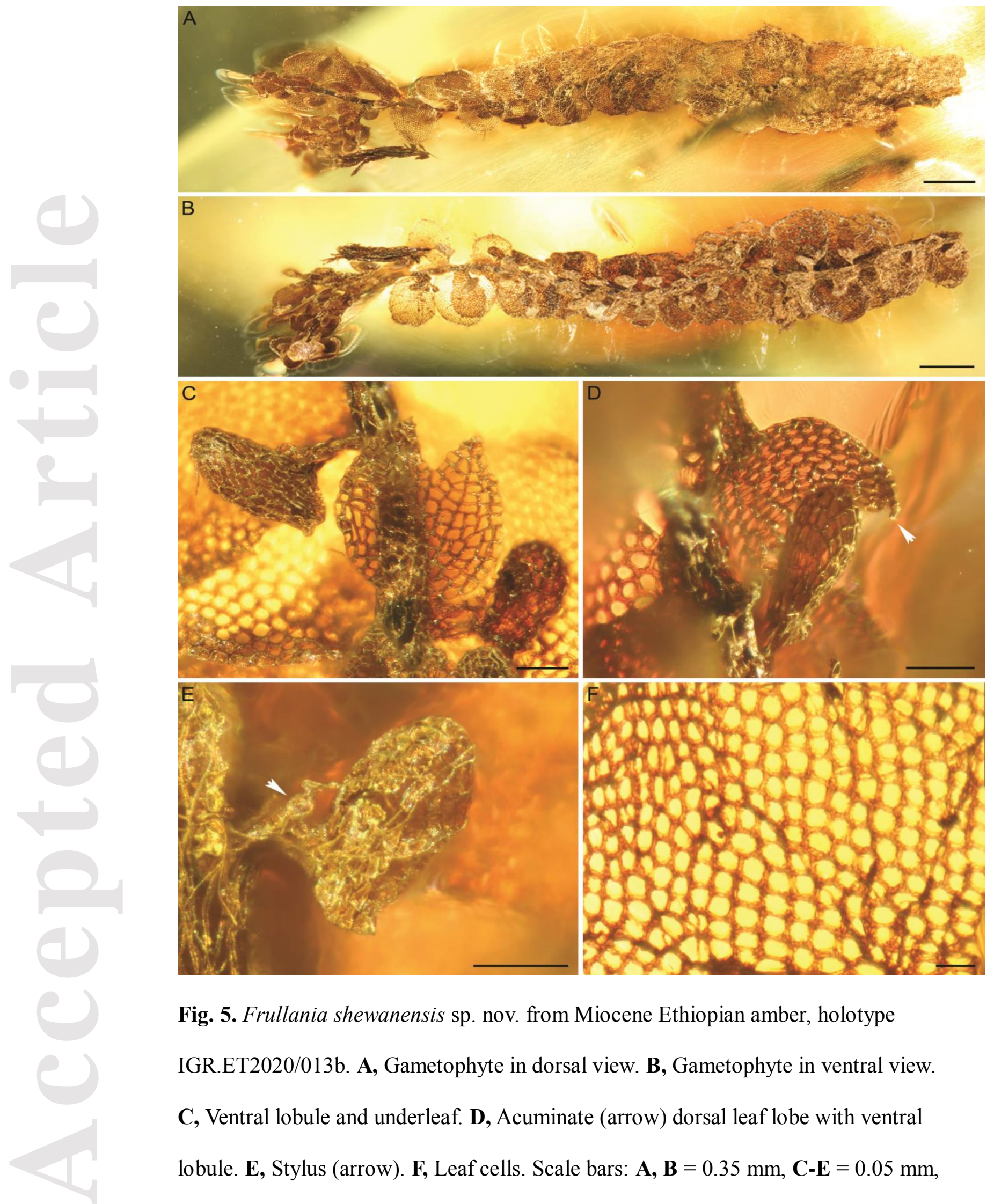

Fig. 5. Frullania shewanensis sp. nov. from Miocene Ethiopian amber, holotype

IGR.ET2020/013b. A, Gametophyte in dorsal view. B, Gametophyte in ventral view.

C, Ventral lobule and underleaf. D, Acuminate (arrow) dorsal leaf lobe with ventral lobule. E, Stylus (arrow). F, Leaf cells. Scale bars: A, B $=0.35 \mathrm{~mm}, \mathbf{C}-\mathbf{E}=0.05 \mathrm{~mm}$, $\mathbf{F}=0.02 \mathrm{~mm}$.

This article is protected by copyright. All rights reserved. 

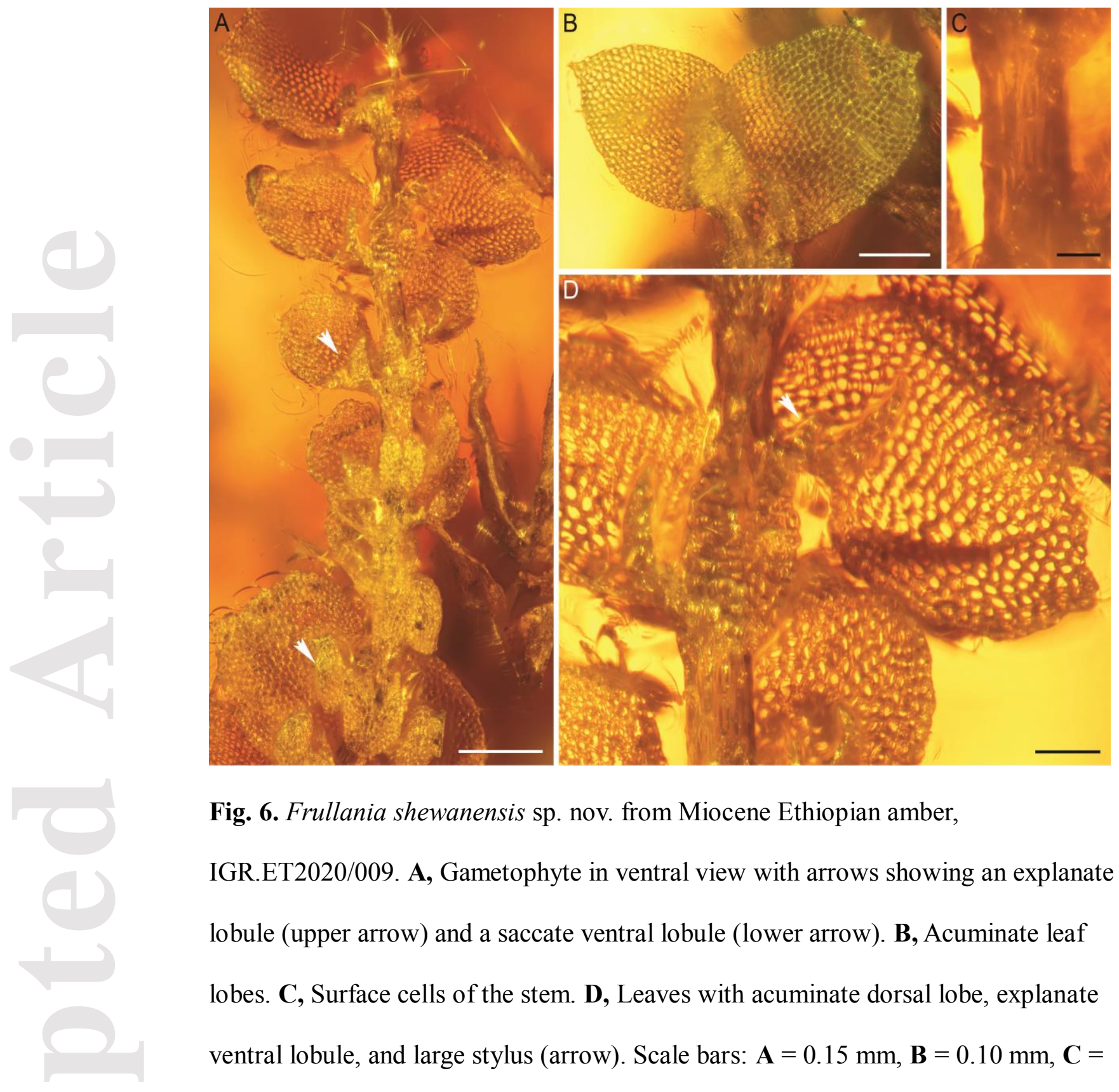

Fig. 6. Frullania shewanensis sp. nov. from Miocene Ethiopian amber,

IGR.ET2020/009. A, Gametophyte in ventral view with arrows showing an explanate lobule (upper arrow) and a saccate ventral lobule (lower arrow). B, Acuminate leaf lobes. C, Surface cells of the stem. D, Leaves with acuminate dorsal lobe, explanate ventral lobule, and large stylus (arrow). Scale bars: $\mathbf{A}=0.15 \mathrm{~mm}, \mathbf{B}=0.10 \mathrm{~mm}, \mathbf{C}=$ $0.03 \mathrm{~mm}, \mathbf{D}=0.05 \mathrm{~mm}$.

This article is protected by copyright. All rights reserved. 

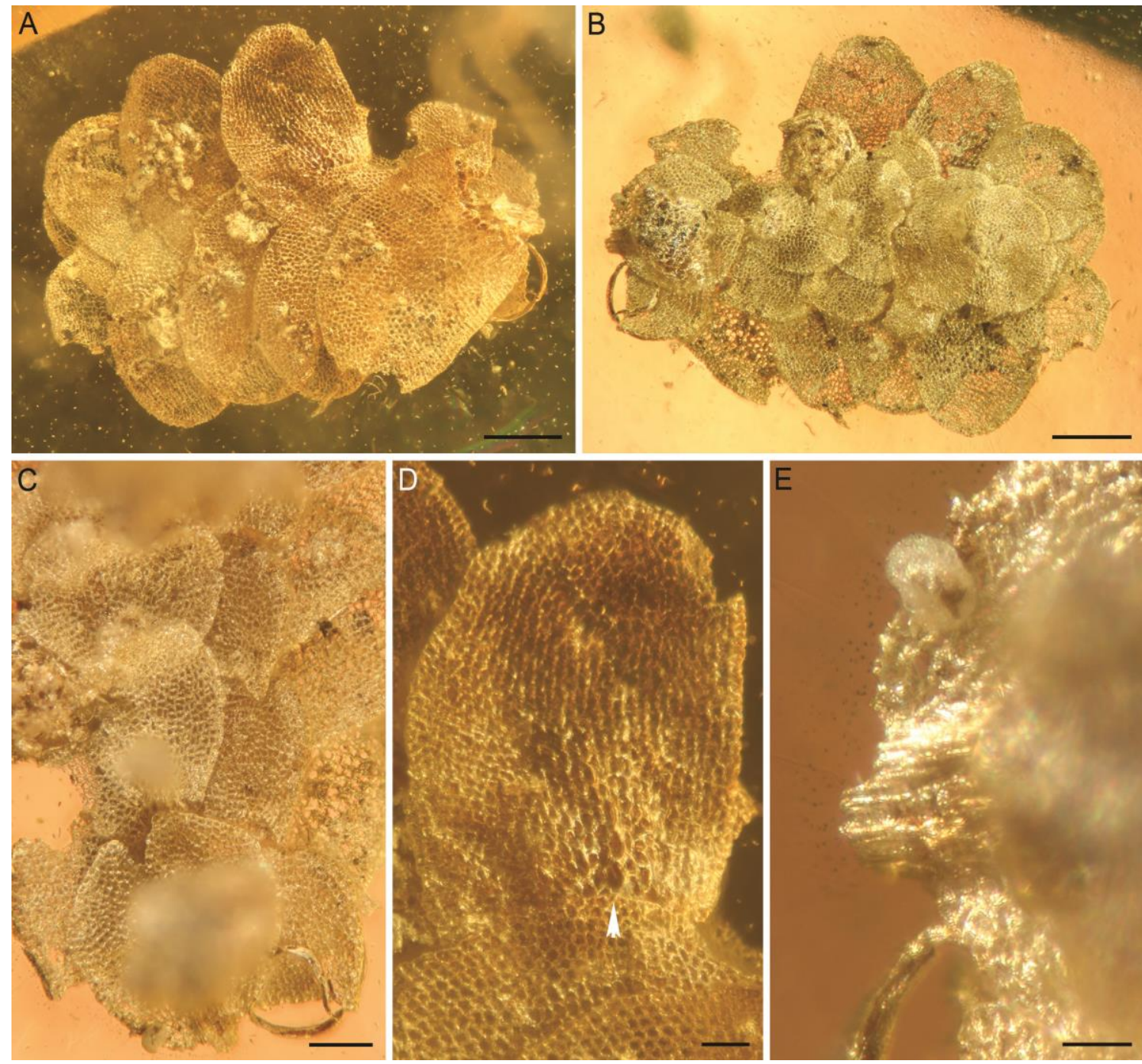

Fig. 7. Frullania palaeoafricana sp. nov. from Miocene Ethiopian amber, holotype

IGR.ET2020/015. A, Gametophyte in dorsal view. B, Gametophyte in ventral view. C, Underleaves. D, Dorsal lobe with possible ocelli (arrow) in dorsal view. E, Surface cells of the stem. Scale bars: $\mathbf{A}, \mathbf{B}=0.20 \mathrm{~mm}, \mathbf{C}=0.10 \mathrm{~mm}, \mathbf{D}=0.05 \mathrm{~mm}, \mathbf{E}=0.03$ $\mathrm{mm}$.

This article is protected by copyright. All rights reserved. 

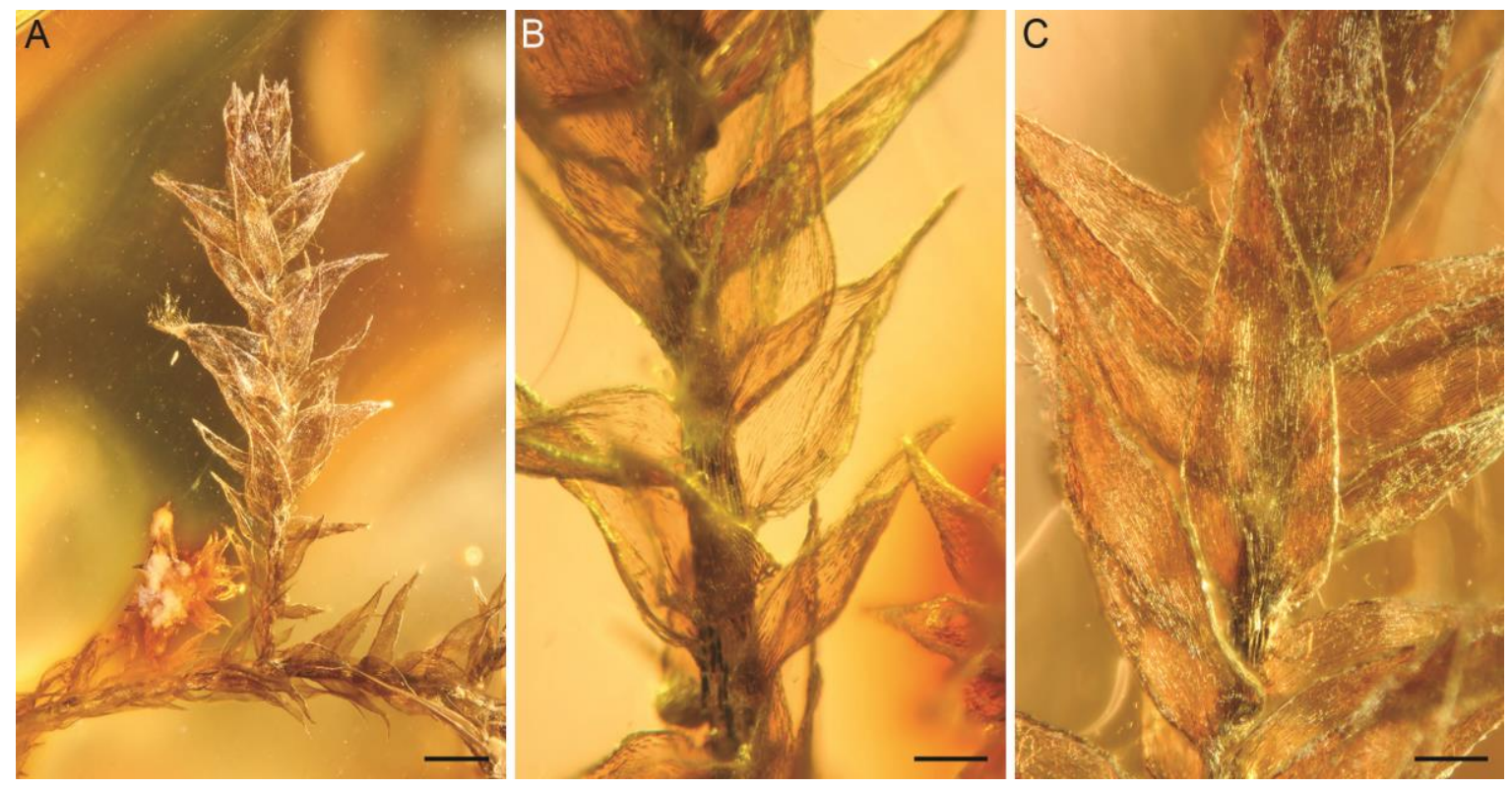

Fig. 8. Isopterygium sp. from Miocene Ethiopian amber, IGR.ET2020/011. A, General view of a shoot. B, Lower part of the shoot, with basal part of leaves and cortex cells. C, Upper part of the shoot, with laminal cells. Scale bars: $\mathbf{A}=0.3 \mathrm{~mm}, \mathbf{B}, \mathbf{C}=0.1$ mm.

This article is protected by copyright. All rights reserved. 

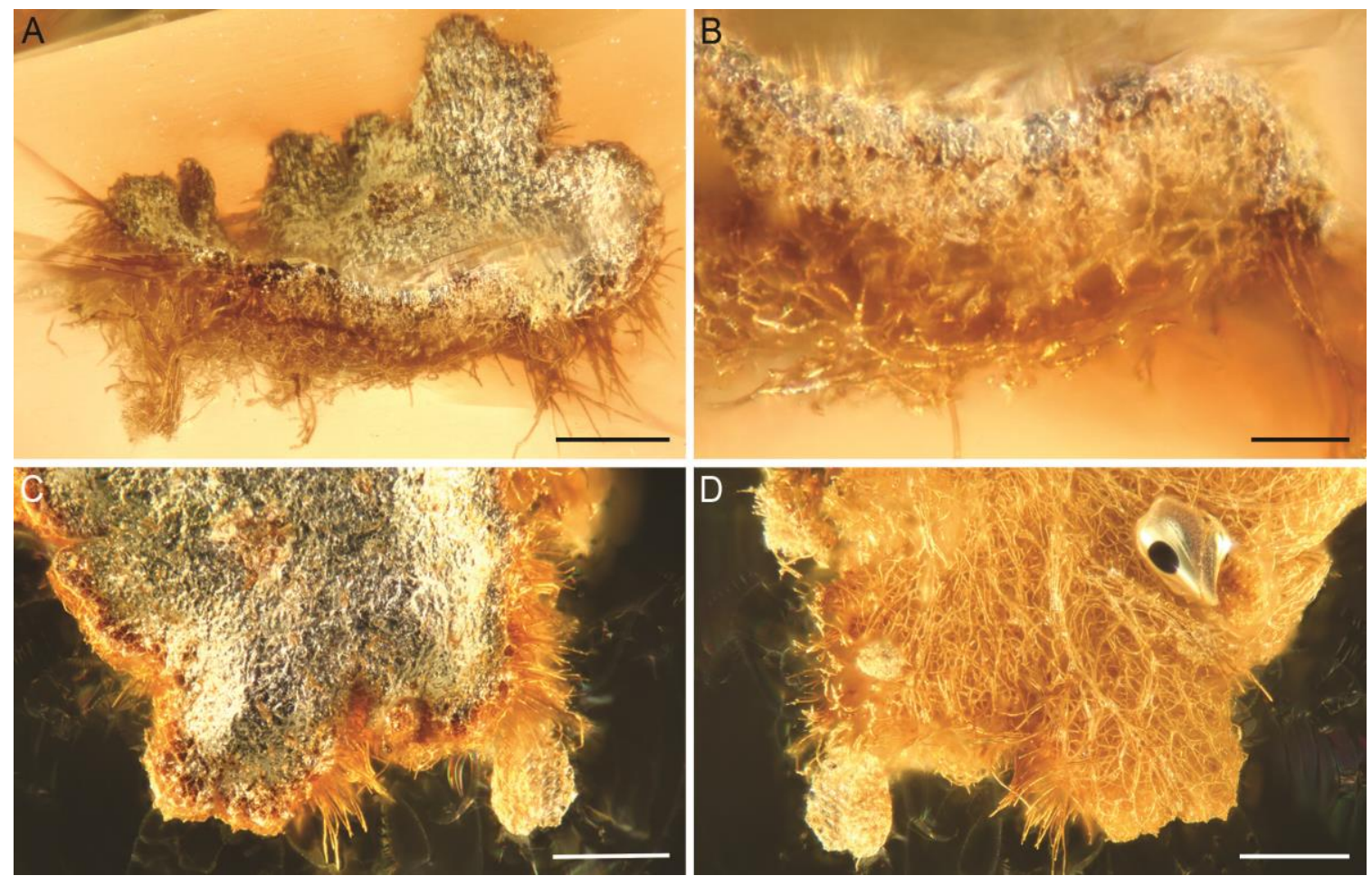

Fig. 9. Lichen of the order Lecanorales from Miocene Ethiopian amber, PB23742. A, Overview of the thallus fragment. B, Stratification of the thallus visible at the breaking point of the thallus fragment showing an upper cortex with a photobiont layer (above), an internal medulla (middle), and a looser lower layer of a hyphal network (below). C, Upper cortex in top view. D, View on lower side of the thallus with loose hyphae. Scale bars: $\mathbf{A}, \mathbf{C}, \mathbf{D}=0.15 \mathrm{~mm}, \mathbf{B}=0.05 \mathrm{~mm}$.

This article is protected by copyright. All rights reserved. 